\title{
Unique amphibole bearing mantle column beneath the Lenin- grad kimberlite pipe, West Ukukit field, NE Yakutia.
}

\author{
Igor Ashchepkov ${ }^{1 *}$, Svetlana Babushkina ${ }^{2}$, Nikolai Medvedev ${ }^{3}$ and Oleg Oleinikov ${ }^{2}$ \\ 1 Institute of Geology and Mineralogy SB RAS, Geology, Novosibirsk, Russian Federation; \\ Igor.Ashchepkov@igm.nsc.ru \\ 2 Institute of Geology of Diamond and Precious Metals, Siberian Branch, Russian Academy of Sciences, Ya- \\ kutsk, Russia; ssta@list.ru \\ 3 Nikolaev Institute of Inorganic Chemistry 3, Acad. Lavrentiev Ave.3, Novosibirsk, 630090, \\ medvedev@niic.nsc.ru \\ * Correspondence: Igor.Ashchepkov@igm.nsc.ru; Tel.: (+79139872605)
}

\begin{abstract}
In the subcratonic mantle beneath Leningrad pipe, West Ukukit field, Yakutia garnet thermobarometry give division to 7 horizons (paleosubduction slabs). Cr-bearing amphiboles $>500$ reveal a broad range changing from $\mathrm{Cr}$ - pargasitic hornblendes to pargasites, edinites, kataforites, K-richterites with increasing pressure determined with new amphibole thermobarometer. Cr-hornblendes compiles the high-temperature branch from 3.5 GPa to Moho for basaltic melt. Amphiboles in the middle eddinites and high-pressure interval reveal different PT ranges from 35 to $40 \mathrm{mw} / \mathrm{m} 2$. Richterites near the lithosphere base both trace low $-\mathrm{T}$ and convective branches. The amphiboles reveal the 9 geochemical groups. The low-temperature varieties reveal Eu minima and $\mathrm{U}, \mathrm{Ba}, \mathrm{Sr}$ peaks high LILE, $\mathrm{Sr}, \mathrm{Rb}$ and troughs in $\mathrm{Nb}, \mathrm{Pb}$. While high $-\mathrm{T}$ varieties have no Eu dips and reveal higher HFSE. Clinopyroxenes and garnets show variable trace element patterns and divisions in groups eth the plume and subduction signs. The contrasting behaviour of $\mathrm{Ta}$ and $\mathrm{Nb}$ is regulated by the rutile partition coefficients likely for primary eclogites. Subduction and $\mathrm{Na}$ and $\mathrm{K}$ (siliceous) types of fluids percolated through the mantle with abundant eclogites causing amphibolization at the different levels of the mantle column. The plume melts produced hybridism and more smooth trace element patterns in reacted minerals, clinopyroxene. monomineral thermobarometry.
\end{abstract}

\section{Introduction}

The northern kimberlite fields in Yakutian kimberlite province (YKP) in Siberia belong mainly to the Early Mesozoic plume activity and mostly are barren in diamonds [1-5]. Several kimberlite pipes like Molokuonamskaya, Leningrad, Ruslovaya, Lorik, Svetlana, Djanga, Aerogeologicheskaya, and Universitetskaya contain diamonds in small amounts $[6,7]$. However, there are plenty of very rich diamond placers in several areas of the northern part of YKP including Kuoyka, Molodo fields, in Ebelyakh and Prilenie [8]. The sources of these rich placers were not determined yet. There is a suggestion that they belong to the Paleozoic or Precambrian time, while the most of pipes in the North of YKP are low Triassic of Cretaceous [4, 5] (Figure.1).

The pipe Leningrad is one of the largest of the known pipes in the Northern part of YKP. Leningrad is the first kimberlite body identified in Russia and Yakutia, which was discovered earlier than the Zarnitsa pipe. It was found by K.S. Zaburdin (NIIGA) in 1952 in the riverbed of the Omonos river, however, the rock was described as "agglomerate tuff" [9]. 


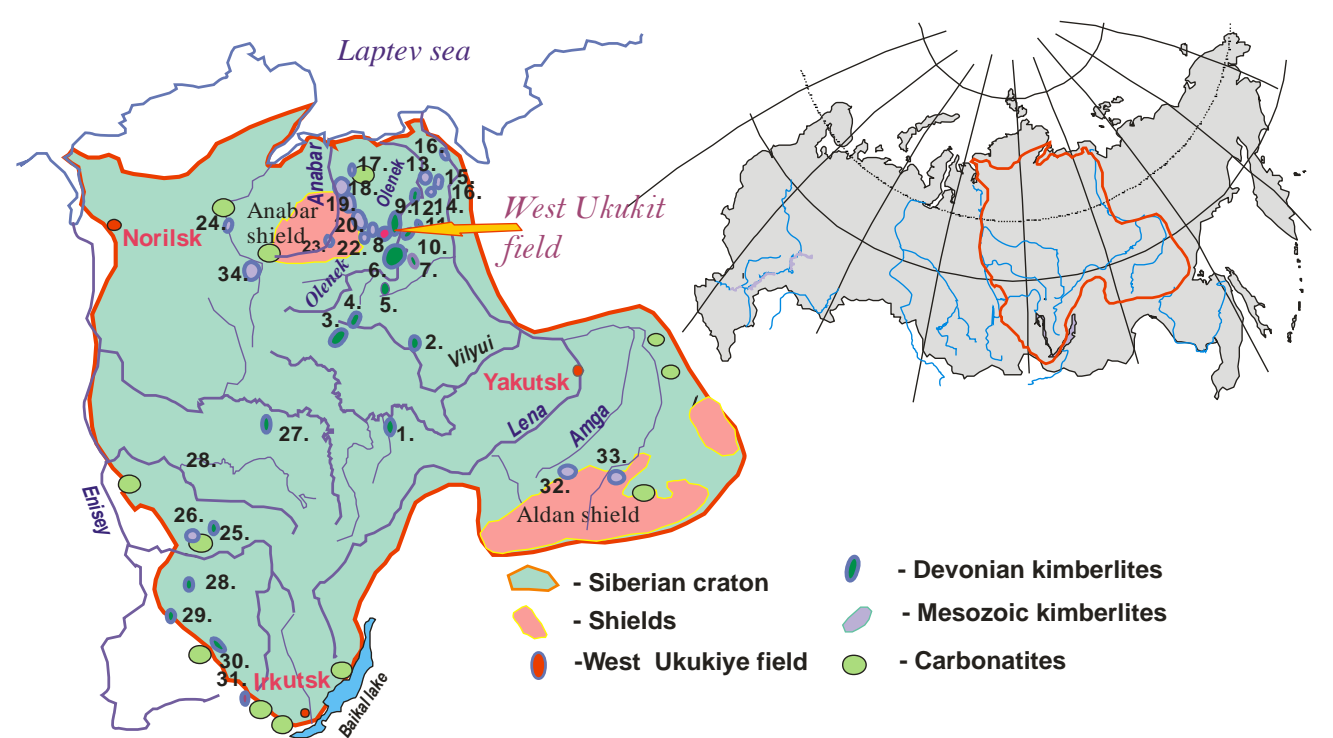

Figure 1. Location of the West Ukukite field and other kimberlite fields in Siberian platform.See legend on the figure. 1. Siberian platform. 2 - Shields. Kimberlite fields: 3.West Ukukite field. 4. Late Devonian fields.5. Lower Triassic and Jurassic fields [1,3]. 6. Carbonatitic massifs. Fields: 1. Malo-Botuobinsky, 2. Nakyn;3. Alakit-Markha, 4. Daldyn, 5.Upper Muna, 6.Chomurdakh, 7. Severnei, 8. West Ukukit, 9. East Ukukit, 10. Ust-Seligir, 11.Upper Motorchun, 12. Merchimden, 13. Kuoyka, 14. Upper Molodo, 15. Toluop, 16. Khorbusuonka, 17. Ebelyakh, 18. StarayaRechka, 19. Ary-Mastakh, 20. Dyuken, 21. Luchakan, 22. Kuranakh, 23. Middle Koupnamka, 24. Middle Kotui, 25. Chadobets, 26. Taichikun-Nemba, 27. Tychan, 28. Muro-Kova, 29. Tumanshet, 30. Belaya Zima, 31.Ingashi, 32. Chompolo, 33. Tobuk-Khatystyr, 34. Kharamai. 35. Manchary; 36. Carnian tuffs

The amphiboles are not common in mantle xenoliths in the kimberlites Worldwide and in Siberia, where they were found in abundant vein association and intergranular associations in Sytykanskaya pipe [10], occur in Yubileynaya, Komsomolskaya pipes of the Alakit field [11]. Rare amphiboles were detected in mantle xenolith of Udachnaya, Zarnitsa and Dalnyaya pipes in the Daldyn field [12-14]. The pargasitic amphiboles are rather frequent in the relatively low pressure (to $4.0 \mathrm{GPa}$ ) xenoliths from Obnazhennaya pipe mainly in veins $[15,16]$.

The mantle column of the West Ukukit region is complex due to layering and unusual mineralogical and petrographic compositions of constituting rocks. The very wide amphibole compositional range suggest their presence in all intervals of the mantle column. The rarity of amphibole-bearing xenoliths and their high alteration explains the difficulties of the interpretation of their position in mantle columns. Only one garnet-amphibole bearing peridotite xenolith was found in our collection. Thermobarometry of these rocks may be done mainly using monomineral methods. The published amphibole barometers are calibrated to $2.5 \mathrm{GPa}$ [17-19]. The experimental high-pressure works give the stability of the Ca- amphiboles commonly to $3.03 .5 \mathrm{GPa}$ [20] and pargasitic to 4.0-4.5 GPa [21] while for the richterites the stability field was found to 8.5 GPa[22]. But a recent study shows the stability of pargasites also to very high pressures [23] to $10 \mathrm{GPa}$.

In addition, the trace element (TRE) geochemistry of the mantle amphiboles is studied only for the most shallow spinel lherzolites in orogenic massifs [24], in alkali basalts [25, 26 ] and most high-pressure rock in kimberlite xenolith [27]. Here we provide more details of the geochemistry of the different amphibole groups and their major and trace element compositions (Supplementary files 1-2)(SF1,2).

The conditions for the formation of amphibole-bearing mantle rocks in the sub-cratonic lithosphere are not clear at all. The mantle amphiboles in the rock exposed in 
the surface were studied only in orogenic massifs [24]. The origin of amphiboles in the sub-lithospheric cratonic mantle lithosphere (SCLM ) which are more common in the northern parts of Siberian craton $[15,16$, our unpublished data] including Leningrad pipe will be discussed. The influence of the subduction material at the ancient time together with the later subduction- and plume related metasomatism well as the hybrid cases may be explained using the geochemistry of the minerals.

Here we give the preliminary features and reconstructions of the mantle columns beneath the West-Ukukit field while the more complete material may be done in the later publications.

\section{Geology}

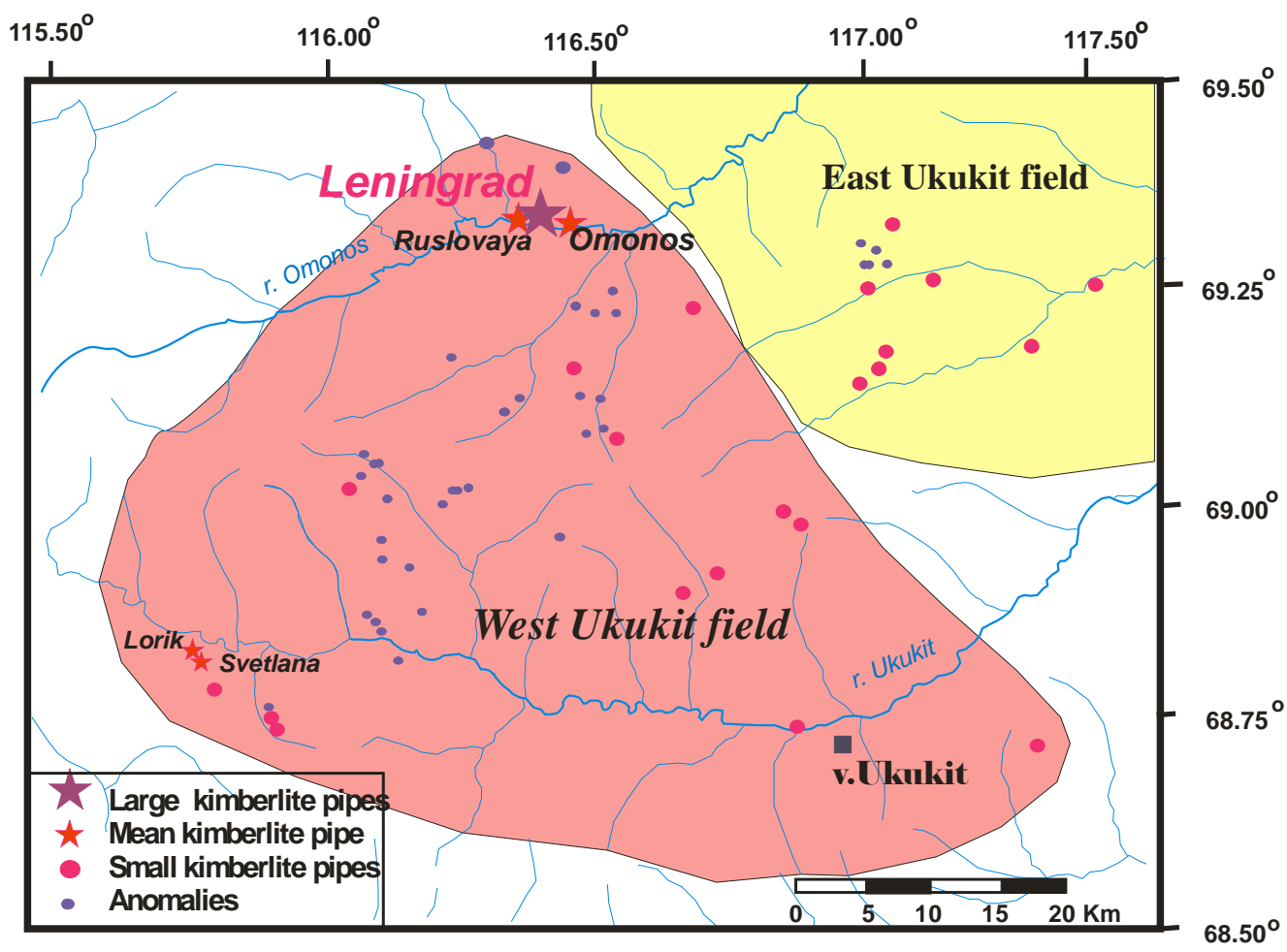

Figure 2. Scheme of the kimberlite pipes location in West Ukukite field. Signs see - figure. Redrawn from [5] with the changes.

Leningrad pipe belongs to the West Ukukit field and is one of the largest pipes in the North of Siberia. The West Ukukit field (Figure 2) includes several large pipes like Leningrad Ruslovaya and Omonos in the northern part and Svetlana and Lorik pipes in the south-western, part of the field [5].

The Leningrad pipe is not covered by the sediments. It consists of several types of breccias referring to at least two 2 main phases [28]. The major phase is autholithic breccia, which contains a huge amount of various xenoliths mainly from the low crust and the nearby-located sedimentary rocks (Figure. 3).

Leningrad pipe contains brightly coloured transparent and well-shaped diamonds but in very small amounts $<0.01 \mathrm{crt} / \mathrm{t}$. Only 330 diamond crystals were described $[7,29]$. The pipe is dated by several methods showing wide variations of ages. The $\mathrm{Rb} / \mathrm{Sr}$ isochrones on mica and bulk-rock give Devonian age from 380 to 350 Ma with the most probable values 368+-1 Ma [5]. The Ar-Ar for the Phl xenocryst gives $385 \mathrm{Ma}$ [30]. The SHRIMP U/Pb age on zircon, refer to $378 \mathrm{Ma}$ [31]. Thus the age of the Leningrad pipe is Devonian (368 Ma) and the earlier ages for the Phl xenocrysts refer most probable to the 
protokimberlites stage. The pipe Svetlana give similar age $365 \mathrm{Ma}$ as well as several other anomalies. However, some small dykes reveal the younger ages to $350 \mathrm{Ma}$ [5].

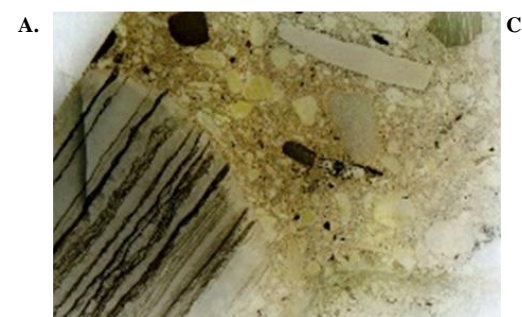

B.

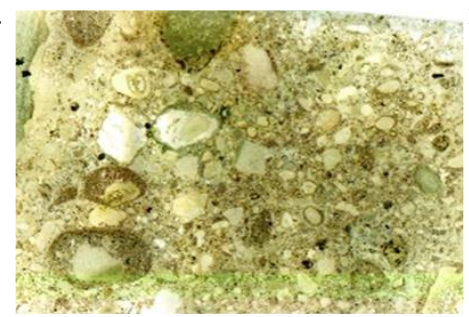

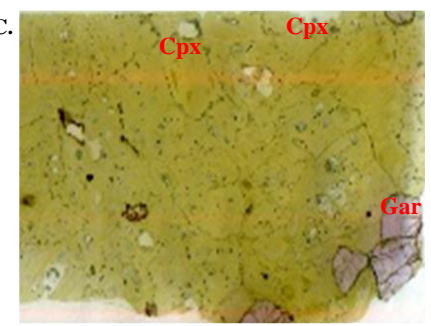

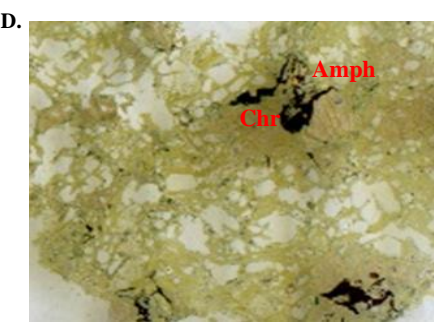

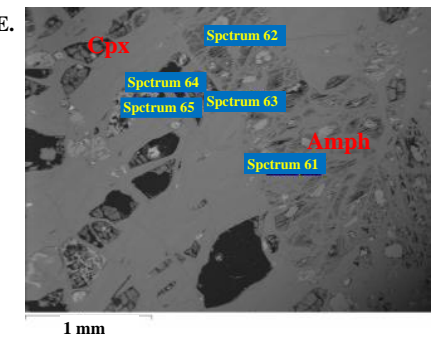

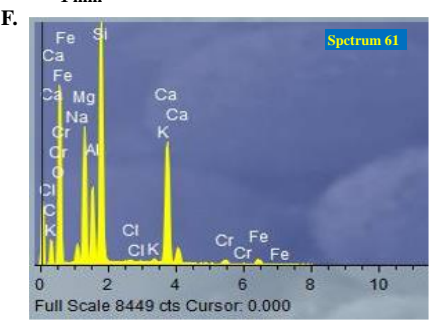

Figure 3. Scanned images of A. Kimberlite from the Leningrad pipe. B. Kimberlite from the Lorik pipe. C. Garnet peridotite xenolith. D. Spinel peridotite with the amphibole and phlogopite. E. Spinel peridotite. F. Spinel peridotite.

\section{Samples}

The pipe was sampled by O.B.Oleinnikov. and K.N.Nikishov during field works in the 1980th. The samples were preliminarily studied by Babushkina S.A using microscopy and electron microprobe analyses (EPMA). They were obtained on partly serpentinized xenoliths and washed concentrates from the kimberlite debris [28]. In the thin sections, it is clear that amphiboles are in intergrowth with the $\mathrm{Cr}$-spinels sometimes with the ilmenites and apatites, and $\mathrm{Cr}$ - rutiles. They are accompanied also by barite and $\mathrm{Sr}$ - carbonates as well as various sulfides (pentlandite, chalcopyrite, pyrrhotite) (SF1).

\subsection{Petrography of kimberlites from Leningrad and Lorik pipe}

The kimberlites from the Leningrad pipe belong to two types: tuffitic kimberlites and autholithic breccias. In the tuffitic kimberlites (Fig.3A), the debris are angular and their amount prevails on the deep-seated mantle material. In autholitic breccia (Fig.3A), the xenocrysts are dominating. Olivines $\left(\mathrm{Mg}^{\prime} 0.85-0.92\right)$ are dominating, pyroxenes, the Ca-perovskites, apatites, amphibolies, ilmenites, magnetites, biotites, phlogopites, serpentines and chlorites as well as carbonatites are common (SF3.) In the Loric pipe which is essentially micaceous, the major mineralogy is similar but it contains also barites, zircons, zirconolite, Cr-rutiles similar to the kimberlites from Priazovie [32-34].

The Leningrad pipe has interesting and rather unusual mineralogy of kimberlite indicator minerals (KIM). The $\mathrm{Cr}$ - diopsides are relatively rare but $\mathrm{Cr}$-bearing amphiboles of various compositions are frequent. Since the peridotitic amphibole is thought to be not very frequent in the kimberlites and SCLM it is interesting to study them in detail. In this pipe, we have a nearly complete set of mantle amphiboles with all transitional varieties between the different groups of amphiboles. They are found in xenoliths and xenocrysts and are abundant in the concentrates.

The rare diamonds in the Leningrad pipe are of very good quality $[6,9,29]$. They are characterized by the relatively low temperatures $1075-1175^{\circ} \mathrm{C}$ for Leningrad according to the $\mathrm{N}$ content and $\delta 13 \mathrm{C} \%{ }_{0}=-4$ which is heavier than for kimberlites in YKP and worldwide $(\delta 13 C \%$ o $=-5.5)$ suggesting the growth from the fluid [9].

The Lorik and Svetlana pipes contain less tuffitic material and amphiboles are not common among the xenocrysts. 


\subsection{Mantle xenoliths kimberlites from Leningrad and Lorik pipe}

The prevailing type of mantle xenolith in Leningrad pipe are garnet (Fig.3C) and spinel harzburgites (Figure 3D-F). The amphiboles were found in thin sections in both types. They commonly are associated with the clinopyroxenes, Cr-spinels and are often in the intergrowth with the phlogopites. Intergrowth with the ilmenites and inclusions of the apatites, Cr-rutiles, barites $\mathrm{Sr}$ - carbonates as well as various sulfides were detected by electron microscope. The sulphides like chalcopyrite, nickeline, keilite, millerite, pentlandite, pyrite, smythite, villamaninite occur in intergranular space. The dominated structures are protogranular and hypidomorphic though deformed also occur. The deepest eddinites and richterites were not found in the xenoliths and thin sections.

\section{Methods of analyses}

\subsection{Electron microprobe (EPMA) analysis}

The EPMA method was used for the minerals from the concentrates. Mineral grains from Leningrad pipe ( 2500) - clinopyroxenes (Cpx) (187), orthopyroxenes (Opx) (9), garnets (Gar) (1387), ilmenites (Ilm) (419), chromites (Chr) (527), amphiboles (Amph) (475) and from Lorik (229) and Svetlana pipe (365) were packed into epoxy mounts. These mineral grains were analyzed in the Analytic Center of IGM SM RAS using electron microprobe analysis (EPMA). It was performed using Camebax Micro and Jeol JXA8320 apparatus according to the published procedure [35,36]. The sizes of the electron beam were 1 micron. The accelerating voltage was $15 \mathrm{kV}$ and the beam current was 15 or $20 \mathrm{nA}$ with 15 seconds counting time. The relative standard deviation did not exceed $1.5 \%$; the precision was close to 3-5\% 2 sigma error. Altogether it was analyzed about 2100 grains (Gar-670, Cpx-142, Amph- 498; Ilm - 420; Chr -380) in addition the analyses of S. Babushkina made in IGDPM SO RAN using Jeol JSM-6480LV microprobe for Leningrad (1220), Svetlana (390) and Lorik pipes (235).

\subsection{Electron microscope analysis}

The detailed mineral compositions of $\sim 420$ grains in thin sections (370) and epoxy mounts (50) were studied using a MIRA 3 LMU scanning electron microscope with an attached INCA Energy 450 XMax 80 microanalysis energy-dispersive system (SEM-EDS) at the X-ray Laboratory of the Institute of Geology and Mineralogy, Siberian Branch, Russian Academy of Sciences [36].

\subsection{Inductively coupled mass spectrometry with laser ablation (LA ICP MS)}

Mineral grains (77) of the kimberlite indicator minerals (KIM) from the concentrate of Leningrad pipe garnets (Gar) (31) and Cpx (18) Ol (2), Amph (69) were analyzed by laser ablation inductively coupled plasma mass spectrometry (LA-ICP-MS) in Nikolaev Institute of Inorganic Chemistry SB RAS using aniCAP Q mass spectrometer (Thermo Scientific) and an NWR 213 (New Wave Research), Nd YAG: UV $133 \mathrm{~nm}$ laser ablation system (analyst N.S.Medvedev). The method has a detection limit of $\sim 10-7$ and the standard deviation of the measurements for most isotopes was about 10-25\% [32]. In total 54 isotopes of elements were analyzed. The NIST 612, 610 SRM were used as the standards. For the internal control $24 \mathrm{Mg}, 29 \mathrm{Si}, 39 \mathrm{~K}, 47 \mathrm{Ti}, 55 \mathrm{Mn}, 52 \mathrm{Cr}$ and $44 \mathrm{Ca}$ isotopes were used to check agreement with EPMA analyses and to estimate the trace element level. The $44 \mathrm{Ca}, 29 \mathrm{Si}, 24 \mathrm{Mg}$, isotopes were used for the normalization of the calculated values. Additionally, garnets and clinopyroxenes from samples 315-254, 315-167 and 315-73 were analyzed in MRAC Belgium by solution ICP-MS [37] were used as internal standards. Analyses were made in long series and there are practically no systematic differences between the element concentrations between different series because they are controlled by internal standards. All data are presented in tables of the supplementary files (SF1-3). 


\section{Mineralogy}

\subsection{Garnets}
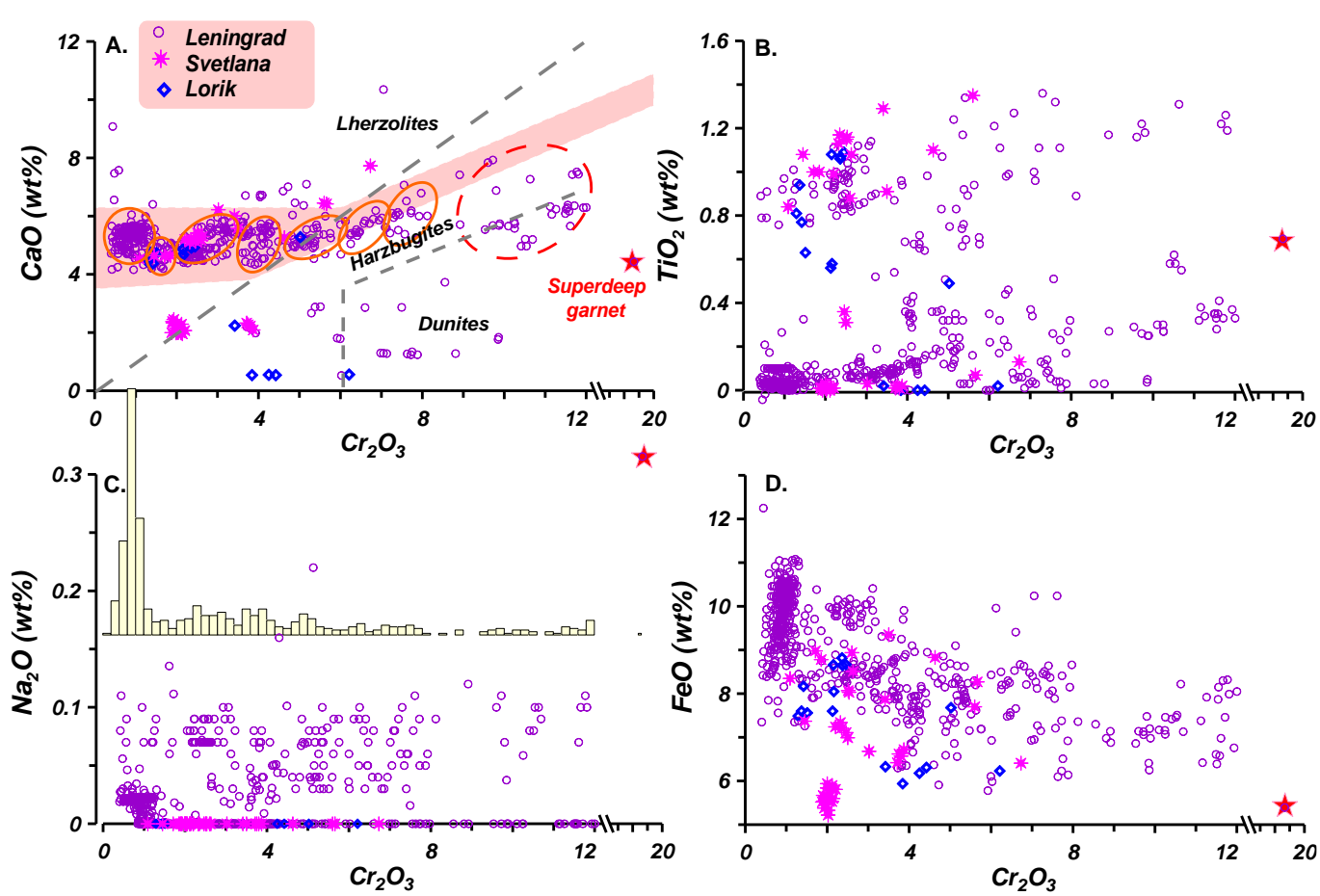

Figure 4. Variations of pyrope garnets compositions from Leningrad pipe in comparison with those from Svetlana pipe. 1. Pyropes from Leningrad pipe. 2. Pyropes from Svetlana pipe. The circles mark the clusters corresponding to the different layers in the mantle structure. The star marks the composition of the $\mathrm{Cr}$ - rich garnet $\left(>18 \% \mathrm{Cr}_{2} \mathrm{O}_{3}\right)$. Fields in $\mathrm{CaO}-\mathrm{Cr}_{2} \mathrm{O}_{3}$ plot are according to N.V. Sobolev et al. [38].

Pyrope garnets were plotted on the $\mathrm{CaO}-\mathrm{Cr}_{2} \mathrm{O}_{3}$ diagram (Figure $4 \mathrm{~A}$ ) covering the intervals from 0.2 to $12.5 \mathrm{wt} . \% \mathrm{Cr}_{2} \mathrm{O}_{3}$. But there is one value at $18.8 \mathrm{wt} . \% \mathrm{Cr}_{2} \mathrm{O}_{3}$ locating within the harzburgite field. The majority of the analyses locate in the lherzolite field according to Sobolev et al [38]. They are grouped into 8 clusters (Figure 4). Small number $<30$ of analyses are located within the dunitic filed. The huge number belongs to the low $\mathrm{Cr}$ varieties as is seen in the $\mathrm{Cr}_{2} \mathrm{O}_{3}$ histogram. They have the steep trend of the $\mathrm{FeO}$ rise together with $\mathrm{CaO}$ but have very low $\mathrm{TiO}_{2}$ content (Figure 4B). Several clusters of the dunitic sub- Ca garnets were also detected starting from 2 wt. $\% \mathrm{Cr}_{2} \mathrm{O}_{3}$. Garnets with $\mathrm{Cr}_{2} \mathrm{O}_{3}>9 \%$ are plotting within the harzburgite field including the highest value $18 \mathrm{wt} . \%$ $\mathrm{Cr}_{2} \mathrm{O}_{3}$. Pyroxenitic garnets are rather scarce and occur mainly in the middle part of the diagram. The $\mathrm{TiO}_{2}$ enrichment from 0.8 to $1.5 \mathrm{wt}$.\% with $\mathrm{Cr}_{2} \mathrm{O}_{3}$ is found mainly in the low $\mathrm{Cr}$ part of the diagram. Comparing published diagrams of garnets and for Svetlana and Lorik pipe [7] those from Leningrad pipe are less abundant and diamond-bearing associations because the capturing interval is shifted to the low-pressure values.

The pyrope - almandine eclogitic garnets are widely distributed. They show the variations in $\mathrm{Fe}$ from 12 to $32 \mathrm{wt} . \% \mathrm{FeO}$ and are separated into two intervals. According to the $\mathrm{TiO}_{2}-\mathrm{Na}_{2} \mathrm{O}$ ratios they belong to the eclogitic non-diamondiferous associations. 

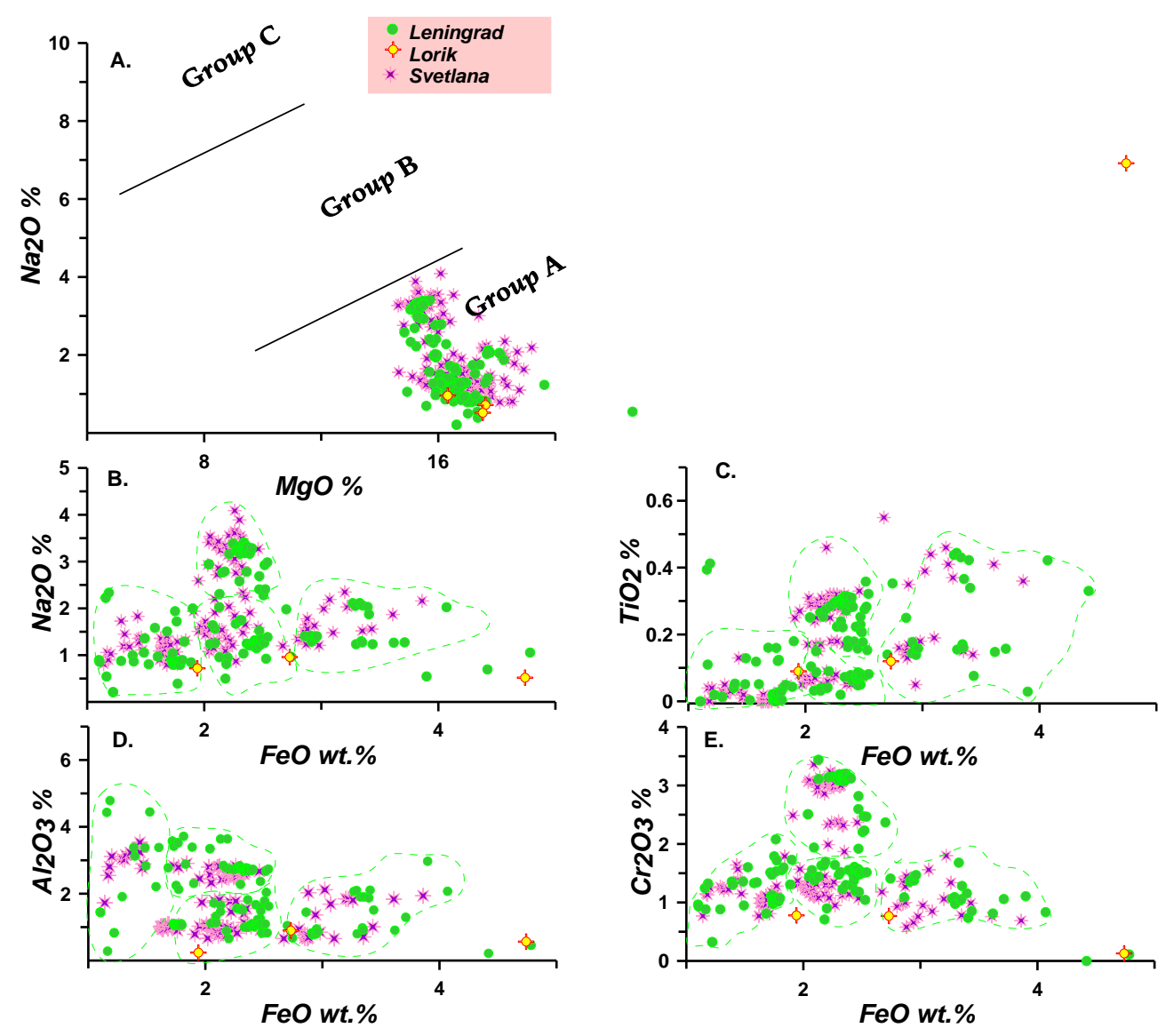

Figure 5. Variations of compositions of Cr-diopsides from Leningrad pipe in comparison with those from Svetlana pipe. 1. Cr-diopsides from Leningrad pipe. 2. . Cr-diopsides from Svetlana pipe. Divisions according to [39].

\subsection{Clinopyroxenes}

The $\mathrm{Cr}$-diopsides from the Leningrad pipe are formed the rather long trend in $\mathrm{FeO}$ $\mathrm{TiO}_{2}-\mathrm{Na}_{2} \mathrm{O}, \mathrm{Al}_{2} \mathrm{O}_{3}, \mathrm{Cr}_{2} \mathrm{O}_{3}$ diagrams to $4 \mathrm{wt}$ \%. In the $\mathrm{MgO}-\mathrm{Na}_{2} \mathrm{O}$ classification diagram, there are no extremal compositions in sodium and all Cpx belong to group A (Figure 5A). $\mathrm{The} \mathrm{Cr}_{2} \mathrm{O}_{3}$ and $\mathrm{Na}_{2} \mathrm{O}$ are rising to 4 wt. \% at $2.5 \mathrm{FeO}$ wt.\% (Figure 5B,E). This is a real metasomatic trend common for pipes with abundant Phl and Amph in xenoliths [10, 11]. In general, these elements decrease with the increase of $\mathrm{FeO}$. The $\mathrm{TiO}_{2}$ is rising with the $\mathrm{FeO}$ and $\mathrm{Al}_{2} \mathrm{O}_{3}$ is decreasing (Figure 5D). One could divide Cpx compositions into 4 groups. The middle part of the diagram with the higher $\mathrm{Ti}, \mathrm{Cr}$, values essentially differs from the common mantle trends for the $\mathrm{Cr}$ diopsides.

\subsection{Amphiboles}

For the classifications, we used the [40] scheme based on the silica content in the main axis (Figure 6), the precise names may be found in the spreadsheet [41]. The amphiboles from Leningrad pipes, in general, form a very extending trend from the Cr-bearing pargasitic hornblendes to pargasites, edinites, kataforites and later to $\mathrm{Na}-\mathrm{K}$ and potassic richterites. The typical $\mathrm{K}$ richterites (Figure 6A,B) are changed to Fe- rich richterites. There are many intermediate varieties, which cover practically all ranges of the compositions of the mantle amphiboles.

We divided the amphiboles mainly of the silica content in the structural formula. In addition, we subdivided the $\mathrm{Fe}$ - rich varieties that occurred among the high silica-rich and low silica varieties. The abundance of the $\mathrm{Cr}$ (Figure $4 \mathrm{~A}$ ) is rising in the middle part 
of the trend as it is also typical of the amphibole Daldyn -Alakit region [11] $\mathrm{TiO}_{2}$ in Leningrad amphiboles are lower (Figure 5J).
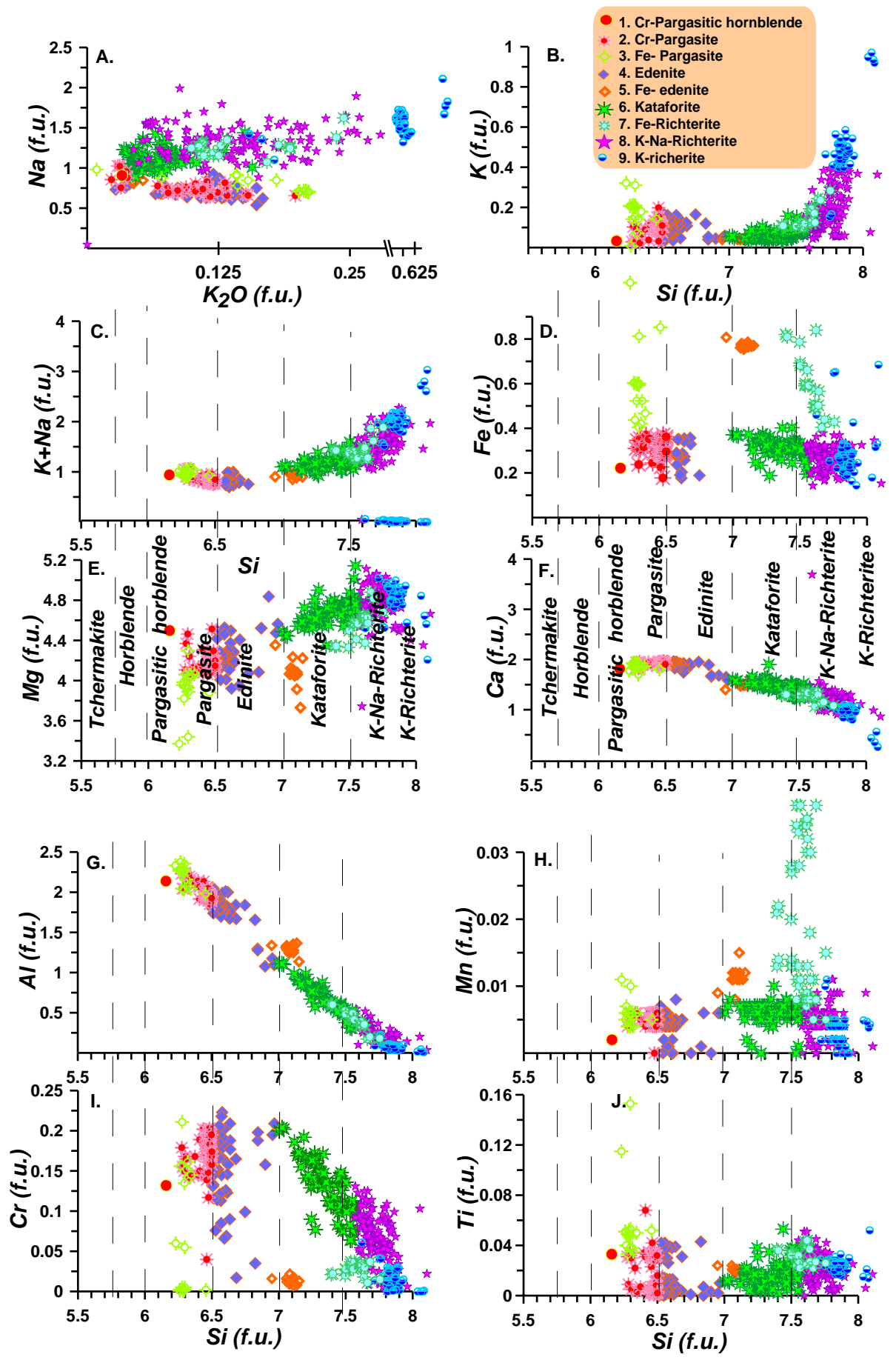

Figure 6. Variations of Cr-amphiboles from Leningrad pipe on the classification diagram [39].

In general, the Leningrad amphiboles in the middle part of the trend are more Ca-rich and less alkaline than amphiboles from Sytykanskaya and Komsomolskaya pipes from the Alakit region [10,11]. (Figure 6C). The amphiboles from the Zarnitsa pipe also essentially differ from K- rich and sodic richterites from the Daldyn area [12-15]. The amphiboles from the Leningrad pipes are also essentially more sodic them those from Daldyn -Alakit fields. The end members are characterized by the essential increase in Fe especially richteritic varieties (Figure 6D). The electron microscope allowed us to determine 
the halogen content of the amphiboles from xenoliths and intergrowth. They all contain chlorine only $0.1-0.3 \mathrm{wt} \%$.

\subsection{Chromites}

The chromites from the Leningrad pipe and other pipes from the WUF are forming several trend $\mathrm{Cr}_{2} \mathrm{O}_{3}-\mathrm{Al}_{2} \mathrm{O}_{3}, \mathrm{Cr}_{2} \mathrm{O}_{3}-\mathrm{MgO}, \mathrm{Cr}_{2} \mathrm{O}_{3}-\mathrm{FeO}$ plots (Figure 7). The plot $\mathrm{Cr}_{2} \mathrm{O}_{3}$ $\mathrm{Al}_{2} \mathrm{O}_{3}$ is lineal as usual but mainly for varieties with $\mathrm{Cr}_{2} \mathrm{O}_{3} 40 \mathrm{wt}$.\%. In the corner with high $\mathrm{Cr}_{2} \mathrm{O}_{3}$ values, there is continuous clouds at the joining of the ulvospinel magnesio-chromite and Fe-chromite trends in both $\mathrm{Cr}_{2} \mathrm{O}_{3}-\mathrm{Al}_{2} \mathrm{O}_{3}-\mathrm{TiO}_{2}$, $-\mathrm{FeO}$ plots (Figure $7 \mathrm{~A}, \mathrm{~B}, \mathrm{C})$. In the $\mathrm{Cr}_{2} \mathrm{O}_{3}-\mathrm{FeO}$ plot there are three separate trends, revealing different isomorphic substitutions and oxygen fugacity's regime. The most $\mathrm{Fe}$ - rich varieties correspond to the oxidized conditions. Interesting that most of the values are from the diamond stability field and essential part close to the field of diamond inclusions.
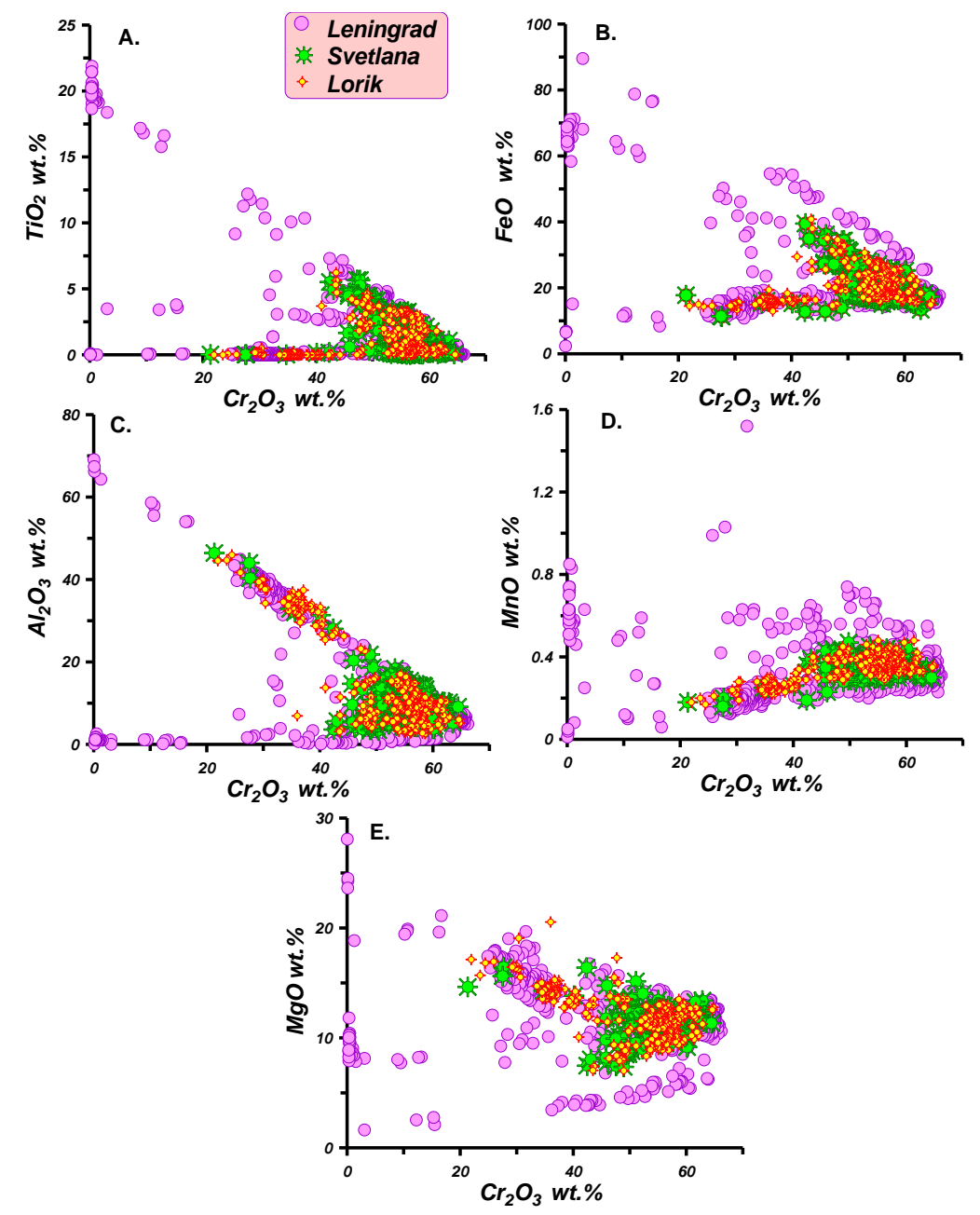

Figure 7. Variations of Cr-spinelides from Leningrad pipe in comparison with those from Lorik and Svetlana pipes.

The MnO plot shows the higher values for the Leningrad pipe compared to the Lorik and Svetlana pipe. Comparisons of the trends for Leningrad, Lorik and Svetlana pipes and their practical coincidence (Figure 7E). Leningrad chromites having at least three different trends possibly formed during several magmatic impulses identical for three pipes.

\subsection{Ilmenites}


The ilmenites from the Leningrad pipe give a long compositional trend on $\mathrm{TiO}_{2}$ and $\mathrm{MgO}$ but there are many low-Mg values and an essential amount of compositions are plotting outsides from the typical kimberlitic and typical SCLM values [42]. In Svetlana pipe, most of the compositions are plotting outside from the kimberlite trend. The $\mathrm{TiO}_{2}$ axis is pressure-dependent [43]. The $\mathrm{TiO}_{2}-\mathrm{Cr}_{2} \mathrm{O}_{3}$ plot shows the joint decrease with the $\mathrm{TiO}_{2}$. The $\mathrm{Cr}$ rich varieties are typical for the high-temperature mantle metasomatites compositions reacted with the protokimberlitic melts [10,11,43]. There are two levels of the $\mathrm{Al}_{2} \mathrm{O}_{3}$ concentrations possibly corresponding to 2 magmatic impulses (Figure 8 ). The $\mathrm{MnO}$ is reaching in several varieties $12 \mathrm{wt} . \%$ and essential amounts of ilmenite grains from the middle interval of $\mathrm{TiO}_{2}$ trend have 2- $4 \mathrm{wt}$ \% which is not common for the typical protokimberlitic systems.
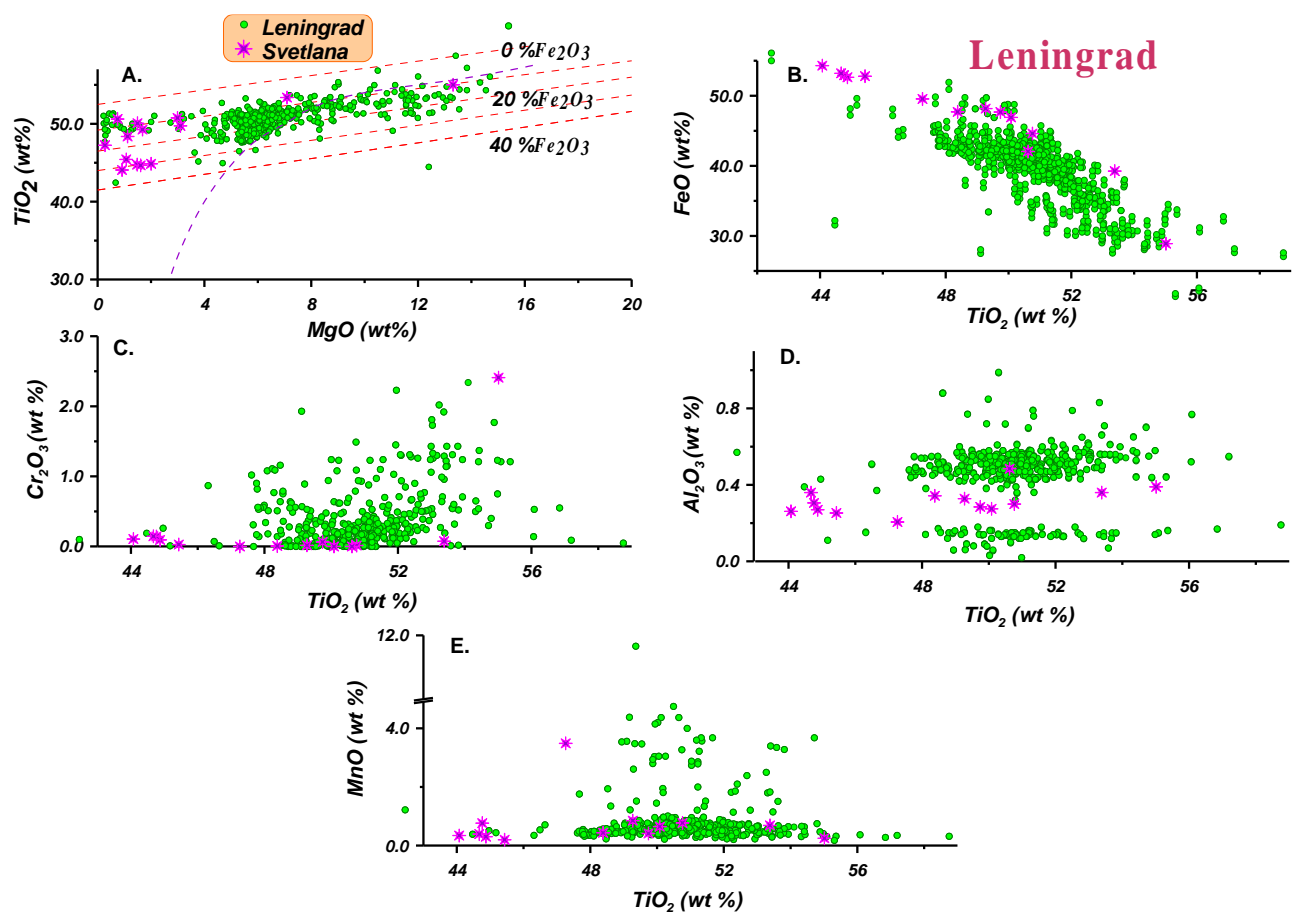

Figure 8. Variations of $\mathrm{Cr}$ picroilmenites from Leningrad pipe. Divisions to kimberlitic and nonkimberlitic types according to Wyatt et al. [42].

\section{Thermobarometry}

\subsection{Single grain thermobarometry.}

For the reconstructions based on the KIM minerals from the concentrate, we used the system of the published thermobarometers for the major peridotitic minerals: clinopyroxenes (Cpx), orthopyroxenes (Opx), garnets (Gar), chromites (Chr), ilmenites (Ilm) [43-45]. For the Cpx in the peridotitic system, jadeite - diopside barometer [37, 44-46] is used. The corrected Jd- Cpx barometry is used also for the omphacites in the eclogitic system [44]. The modified $\mathrm{Cr}$ - garnet barometer [44,45] is used for pyrope garnets. The eclogite garnet barometer gives appropriate results for the $\mathrm{Ca}-$, $\mathrm{Na}$-bearing garnets using the dependence of $\mathrm{Na}$ in garnet from pressure with $\mathrm{FeO}$ varying from 12 to $30 \mathrm{wt}$ \% [44].

For the Cr-spinels and chromites, we calibrated their dependence of $\mathrm{Cr} \#$ on pressure separately in garnet and spinel mantle facies [46]. The barometer is in combination with the spinel-olivine thermometer of Taylor et al. [47] where the Fe\# $\mathrm{Ol}$ is calculated from Fe\#Ilm and ${ }^{\circ} \mathrm{C}$ by the empirical equations. 
For the calculation of the oxygen fugacity the monomineral version of the G.Gudmundsson and B.Wood [48]. for ilmenite and chromite according to [47] in monomineral version, for ortho- and clinopyroxenes the polynomial formulas [49] were used.

All these thermobarometers are combined in the PT program Ter55 written in FORTRAN-70 [50].

\subsection{Monomineral amphibole thermobarometry.}

To locate the position of the separate amphibole grains in the mantle column is impossible with the existing published thermobarometers for the amphiboles because they use only Ca- amphibole compositions and give pressures only for the relatively low-pressure mantle amphiboles [17-19] varieties. The first author developed a new thermobarometric method [51] using the KD using Si-Al and K, Na-Ca re-distributions and the influence of other components and equations in analogy with the universe clinopyroxene barometer [44]. In this paper, this method was essentially corrected. It was recalibrated with the minerals of the high-pressure experiments to $8 \mathrm{GPa}$ and was checked using the material from the kimberlite xenoliths $[10,11,27,71]$ for cross-correlations of PT estimates.

As the thermometer, the method of K.Ravna [52] based on the Fe-Mg (accounting Ca and other components) distribution between garnet and amphibole is used. It was transformed to the monomineral version. We added the corrections to the published version of the paper which give a better coincidence with the geotherms and trends of clinopyroxenes and garnets on PTX diagrams. The correlations of the calculated and experimental values are represented on the diagram (Figure 9). The list of the used papers and compositions of the experiments are given in supplementary file SF5.

Full methodology and calibration of the new version of the amphibole thermobarometer for the deep-seated rocks will be described in a separate paper. The equations of the amphibole thermobarometer are given in the appendix.
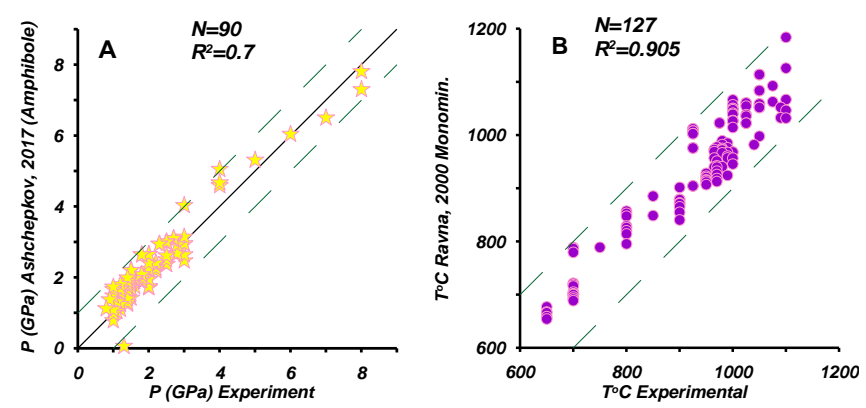

Figure 9. Correlations of the calculations with the experimental values or the amphibole thermobarometer.

The new version of the PT program and files for the calculations are in the supplementary files (SF 4,5)

\subsection{Reconstruction of mantle sections beneath the West Ukukit kimberlite field.}

The complex nature of the processes in the mantle lithosphere beneath the Leningrad pipe is visible in the PT diagram with the very rather complex geotherm branches. 


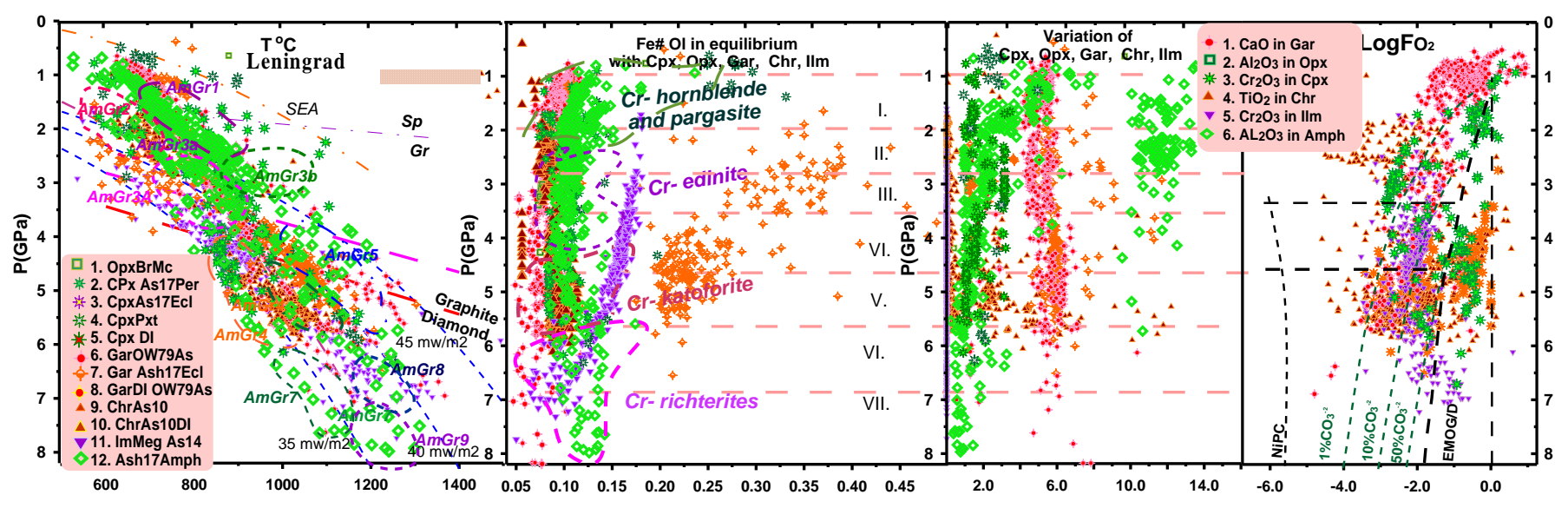

Figure 10. PTXfO2 diagram for the minerals xenocrysts from Leningrad pipe.

Signs: 1. Opx: $\mathrm{T}^{\circ} \mathrm{C}$ [53]-P(GPa)[54]. 2. Cpx: $\mathrm{T}^{\circ} \mathrm{C}$ - [55] - P(GPa) - [44] (for $\mathrm{Cr}$-diopsides); 3.The same for pyroxenites and $\mathrm{Fe}-\mathrm{Cr}$-diopsides. 4. The same for eclogites and pyroxenites; garnet: 5 . $\mathrm{T}^{\circ} \mathrm{C}$ [56] -P(GPa) [44]. 6. [58]- [44] for eclogites; chromite: 7. T० ${ }^{\circ}$ [57] -P(GPa) [46]; 8. Ilmenite megacrysts: 7. $\mathrm{T}^{\circ} \mathrm{C}$ [47]- $\mathrm{P}(\mathrm{GPa})[46] ;$ Amphibole: 9. $\mathrm{T}^{\circ} \mathrm{C}-\mathrm{P}[52]-\mathrm{P}(\mathrm{GPa})$ [51]. The horizontal dashed line at 3.5 and 4.5 GPa corresponds to the Graphite-Diamond boundary $[59,60]$ at 35 and $40 \mathrm{mWm}-2$ respectively. Conductive geotherms [61] The field for P-FO2 diagrams and lines of $\mathrm{CO}_{3}$ - concentration in melts are from $[62,63]$.

The garnets are forming a wide PT field that is located in the lower part starting from 6 between 40 and $35 \mathrm{mw} / \mathrm{m}^{2}$ conductive geotherm and in the upper part near 2.0 $\mathrm{GPa}$, it is slightly above $45 \mathrm{mw} / \mathrm{m}^{2}$ geotherm. Below $6 \mathrm{GPa}$ there is a wide scattered convective branch traced together by the Ilm and Gar PT estimates. The additional convective branch is traced by the garnets from 4 to 5.5 GPa just at the diamond - graphite transitions [59, 60](Figure 10).

Amphiboles of different types trace practically all geotherm branches formed by Cpx and garnets. The low pressure are covering the 2.5-0.8 GPa interval and are divided into relatively high - Al-rich hornblendes and lower -Al - pargasites varieties. The PT estimates for edinites are tracing the middle part of the SCLMin pressure interval from 2.5 to 4.5 GPa. The kataforites and richterites are deeper and are found in 4.5-6 GPa interval. They give more high-temperature (HT) branches in general which are close to those formed by Cpx's and HT pyrope's PT estimates. The K-Na richterites give high-temperature (LT) geotherm which is correspondent to those of pyrope diamond inclusions [64]. In addition, The Fe- enriched richterite varieties give the deviations to the high-temperature geotherm for ilmenites and high-temperature garnets are tracing convective branch. The general feature of PT conditions for amphiboles is their division to HT and LT branches in all pressure intervals. (Figure10).

The general feature of PT conditions for amphiboles is their division to HT and LT branches in all pressure intervals.

In the SCLM mantle beneath Leningrad pipe, West Ukukit field, Yakutia, the thermobarometry for garnets, $\mathrm{Cpx}, \mathrm{Chr}$, Amph give division to 7 horizons (paleosubduction slabs) (Figure 10).

The oxidation state of the pyrope garnets is common and form the trend between $1-10 \% \mathrm{CO}_{3}$. The eclogitic and pyroxenitic Cr-low garnets are more oxidized to QMF buffer (Quartz-Magnetite= Fayalite) $[62,63,65]$. The chromites are the same in general but at 3-2 GPa they are anomalously reduced. The part of the clinopyroxenes is following to pyrope trend. But the those located within $6.5-4 \mathrm{GPa}$ intervals are more oxidized and are plot- 
ting near the boundary Enstatite- Magnezite- Olivine- Garnet = Diamond (EMOG/D)[62,63] buffer to 0 QMF. The ilmenites reflecting the conditions of the picroilmenites shows FO2 values following EMOG/D buffer, in general, being more oxidised at the lithosphere base.
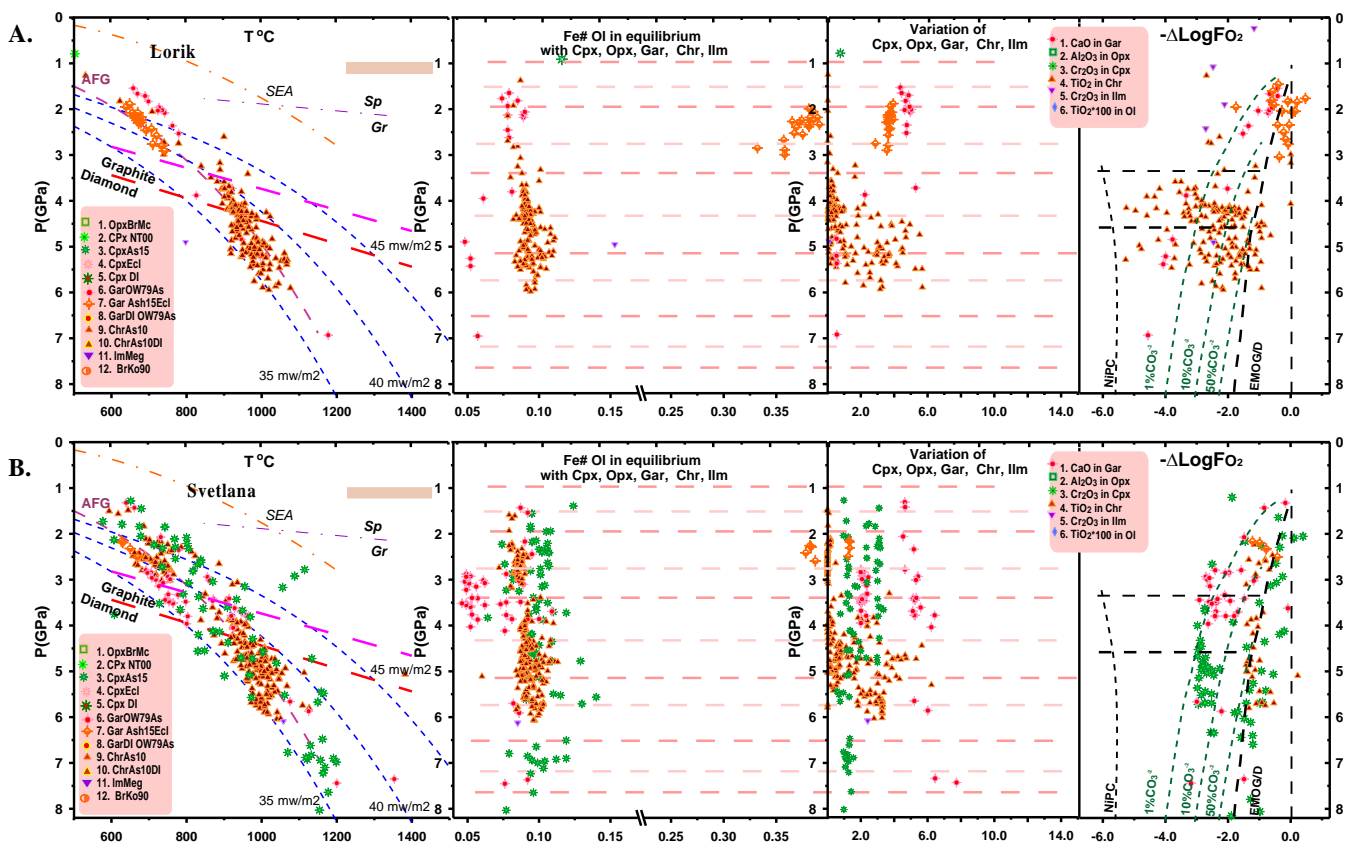

Figure 11. PTXfO2 diagram for the minerals xenocrysts: a) Lorik pipe; b) Svetlana pipe. Symbols are the same as in Figure10.

Two pipes from the SW part of the field also contains KIM used for the thermobarometric reconstructions. Both of them contains mainly chromates. The chromites from the Lorik pipe (Figure 10A) show the low-temperature conditions at the lithosphere base at $6 \mathrm{GPa}$ which is followed by the advective trend to $3 \mathrm{GPa}$ (Figure 11). The pyrope garnets are represented mainly by the sub-calsic varieties tracing low-temperature geotherm. In the upper part, the geotherm is composed of the PT estimates for the wehrlitic garnets and Ti-rich Cr-spinels. The PT conditions for the $\mathrm{Cr}$-spinel from the Svetlana pipe are nearly the same. But garnets mostly give the 3-4 GPa interval and are sharply divided into sub-calsic and pyroxenitic varieties. The latter sow the conditions up to 7.5 GPa referring to $40 \mathrm{mw} / \mathrm{m}^{2}$. The clinopyroxenes trace all parts of the geotherm for garnets and Cr-spinels. They also create the relatively Fe-rich hot branch at $6.0 \mathrm{GPa}$ commonly associated with deformed peridotites.

\section{Geochemistry of the minerals}

\subsection{Garnets}

We divided garnets into 7 groups according to trace element patterns. The group with the highest REE level ar 100/C1n refer to the crust granulites and they show deep minimums in high field strengthen elements (HFSE).

Analyzed peridotitic garnets from the Leningrad pipe of the prevailing lherzolitic type reveal mostly regular semi-round rare earth elements (REE) patterns with the low LREE level. Common lherzolites (GLh) in the spider diagram for trace elements (SDTR) reveal the evident elevations in $\mathrm{Zr}-\mathrm{Hf}$ typical for the metasomatic phlogopite bearing mantle and rather high $\mathrm{Ta}, \mathrm{Nb}, \mathrm{U}$ and $\mathrm{Th}$. The trace element (TRE) spider diagrams show mot very low minima in $\mathrm{Sr}, \mathrm{Pb}$ and deep in $\mathrm{Ba}$ and low large ion lithophile elements (LILE) except for Rb. Harzburgitic garnets $(\mathrm{GrHz})$ display small minima in MHREE and essen- 
tially lower all incompatible elements from the left part. The depleted harzburgites GrHrD show also lower LREE part and all incompatible elements. As common the garnets from dunites (GrDun) and moderately low levels of incompatible elements and HFSE and some of them show even elevated levels of LILE. There are two types of pyroxenitic garnets. The 1st one GrPxt1 reveal the hump in the REE pattern and the SDTR show the high incompatible element level including HFSE with the peak at U. the second GrPxt2 display the flattened REE and slightly elevated LREE and LILE while HFSE are slightly lowered (Figure 12).
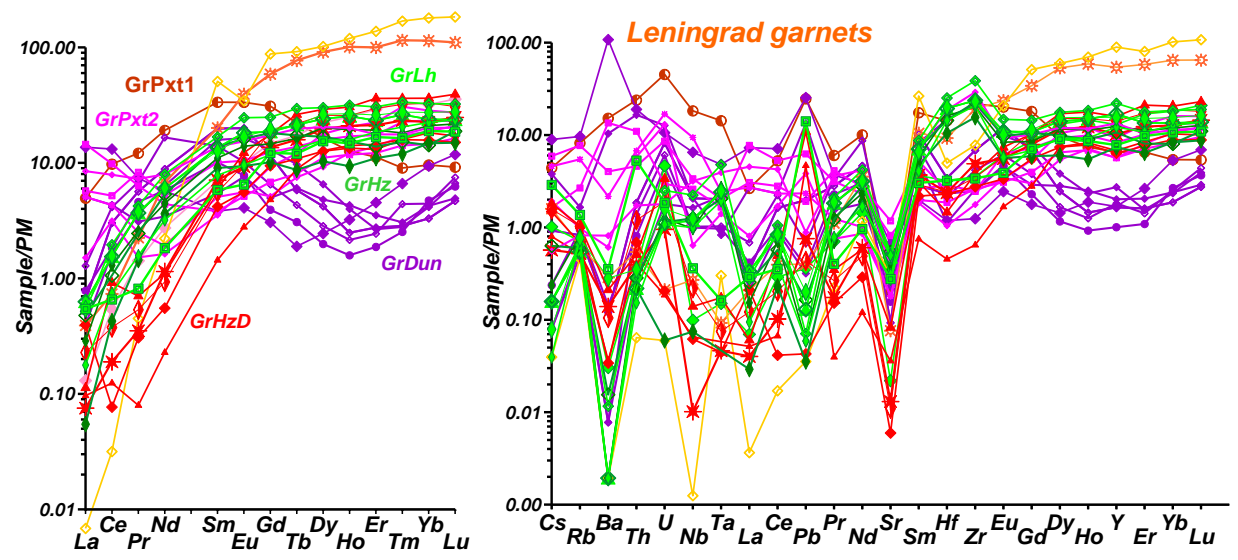

Figure 12. REE patterns and TRE spider diagrams for the pyrope garnets from Leningrad pipe. Normalization REE to [67] and TRE spider diagrams to [68].

\subsection{Clinopyroxenes}

The clinopyroxenes were divided into 5 groups according to trace elements. The samples from Gr1Cpx show REE level at 300 or more in La and inclined $\mathrm{La} / \mathrm{Yb}_{\mathrm{n}} \sim 10$, Th SDTR have small minimums in HFSE and rathes low LILE but Th-U is slightly higher. The Cpx from the Gr2Cpx are lower in La level but are more inclined La/ $\mathrm{Ybn} \sim 12-15$. The HFSE are varying and mostly low similar to those in intergrowths with the ilmenites like in Dalnyaya pipe [14]. The Gr3Cpx (pyroxenitic) display higher REE inclination and nearly straight line REE patterns. The SDTR is more smooth and the left part of the diagram (incompatible ) is very low. The REE patterns from with lower REE with Lan $\sim 15$ concentrations have minima in $\mathrm{Ta}, \mathrm{Nb}$ and more flat $\mathrm{Zr}-\mathrm{Hf}$. The samples from the Gr5Cpx have different REE - one (a) displays very high LREE $>100$ and $\mathrm{La} / \mathrm{Yb}$ ratio the second nearly flat pattern at $\sim 10$ Lan level typical for spinel facie. But they have very huge $\mathrm{U}$-Th peaks but like those for the carbonates. They have minimums in $\mathrm{Hf}, \mathrm{Pb}, \mathrm{Nb}$ and LILE.
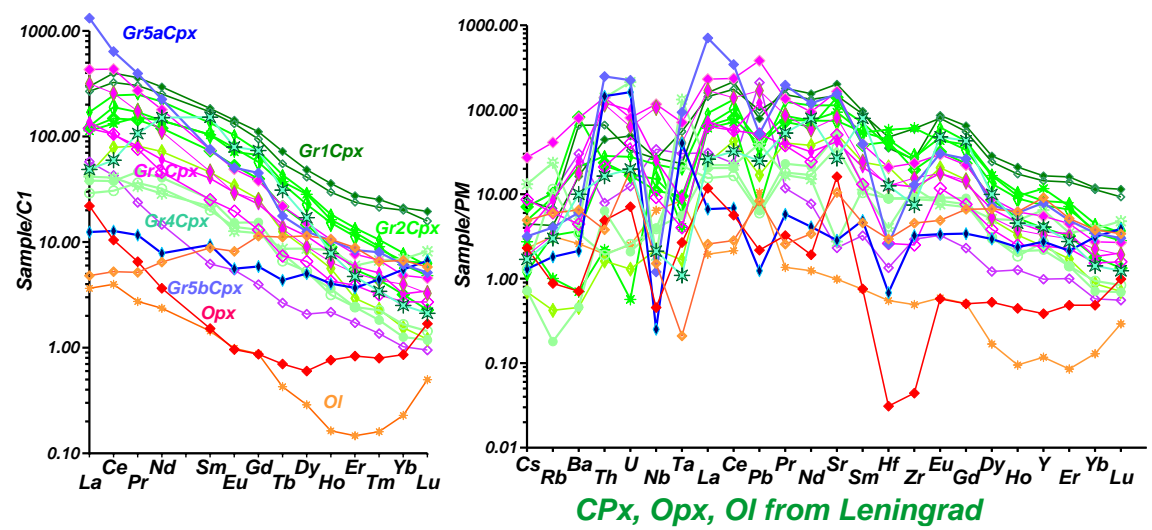

Figure 13. REE patterns and TRE spider diagrams for the clinopyroxenes, orthopyroxenes and olivine from Leningrad pipe. Normalization is the same as in Figure 11. 


\subsection{Amphiboles.}

The low-pressure $\mathrm{Cr}$ - pargasitic hornblendes (AmGr1) show highly inclined and deeply concave downward REE patterns. All of them have the peaks in Eu reveal rather high LREE level - Lan 100 C1 and they have essential depressions in HMREE part with the minima near Ho-Dy REE patterns. The SDTR for most of them shows strong peaks in $\mathrm{Ba}, \mathrm{U}$ and smaller ones in Ba. They reveal HFSE minima except for $\mathrm{Y}$. The more HT varieties (Gr2a) show similar patterns but much lower in REE and less inclined pattern with the LREE at 50-10/C1 and they reveal the minima in $\mathrm{Nd}$ and Ta are less deep and $\mathrm{Hf}-\mathrm{Zr}$ are highly variable and minima or even maximum in $\mathrm{Zr}$ Hf. The amphiboles from Gr2b show a much lower LREE level (Lan $\sim 10 / C 1$ ). The amphiboles (mainly edenites) from AmGr3 are subdivided into 2 subgroups. Groups $3 a$ and $3 b$ have a similar inclination of REE patterns with $(\mathrm{Gd} / \mathrm{Yb})_{\mathrm{n}} \sim 5-7$ ratios and slightly bell-like - left part of the pattern from La to Sm. The MHREE is slightly concave downward from $\mathrm{Yb}$ to Ho. The Gr3a with the higher REE level and Lan 150 to 100 reveals the evident Eu minima. The TRE spider-diagram for Gr3a show the minima in $\mathrm{Zr}-\mathrm{Hf}$ and contrast $\mathrm{Nb}$ peaks and minima or they have both moderately depleted LILE group with local Ba peak. The U also display peaks. The samples from $\mathrm{Gr} 3 \mathrm{~B}$ have no Eu anomalies. They have elevated $\mathrm{Ta}, \mathrm{Nb}$ and slightly elevated $\mathrm{Zr}, \mathrm{Hf}, \mathrm{Y}$ very low Th. The kataforites from the middle high-pressure interval are close in REE patterns with the inclined from ND to $\mathrm{Yb}$ part and more flattened from $\mathrm{La}$ to $\mathrm{Nb}$ part and without no Eu anomalies. The level of Lan $100-40$ or higher. The spider diagrams have gently decreased from the $\mathrm{Nd}$ to $\mathrm{Yb}$ part with the small fluctuation in $\mathrm{Hf}$ and Sr and slightly elevated $\mathrm{Y}$ and Pn minimum. The definite feature is a strong $\mathrm{Nb}$ peak and $\mathrm{Th}$ trough rather high $\mathrm{U}$ and elevated LILE. The samples from the AmCr6 have the same inclined branch from $\mathrm{Sm}$ to $\mathrm{Yb}$ as the previous group and the right part reveal spreading fan-like patterns. The SDTR is nearly the same but Hf is a bit lower. The $\mathrm{Nb}$ show the great trough and $\mathrm{U}$ relatively strong peak. the LILE level is slightly lower. The high-pressure amphiboles K-Na richterites typically reveal higher inclinations compared to all previous groups $(\mathrm{Gd} / \mathrm{Yb}) \mathrm{n} \sim 20-30$ with the minima in HMREE near Er-Tm. The amphiboles from AmGr7 corresponding to the low-temperature geotherm reveal nearly straight-line REE patterns with the very high level of LREE (Lan 1000/ C1) with the Eu minima and flattened HREE part fro AmGr7B samples. The high U level was detected for several samples, most of them show Ba peaks and elevated $\mathrm{Rb}$ and $\mathrm{Sr}$. The $\mathrm{Zr}-\mathrm{Hf}$ mostly reveal minima $\mathrm{nb}$ and Ta are fluctuating. One spectrum of AmGr7b for the $\mathrm{Na}$ - richterite show a less inclined REE patterns spectrum of AmGr7b for the K-Narichterites show a less inclined REE pattern with the more expressed minima from $\mathrm{Yb}$ to Dy, high LILE and Sr and the TRE pattern with the minima in the all HFSE except for Y and also in $\mathrm{U}$, Th with the more expressed minima from $\mathrm{Yb}$ to Dy, high LILE and $\mathrm{Sr}$ and the TRE pattern with the minima in all HFSE except for $Y$ and also in $U$, Th. 

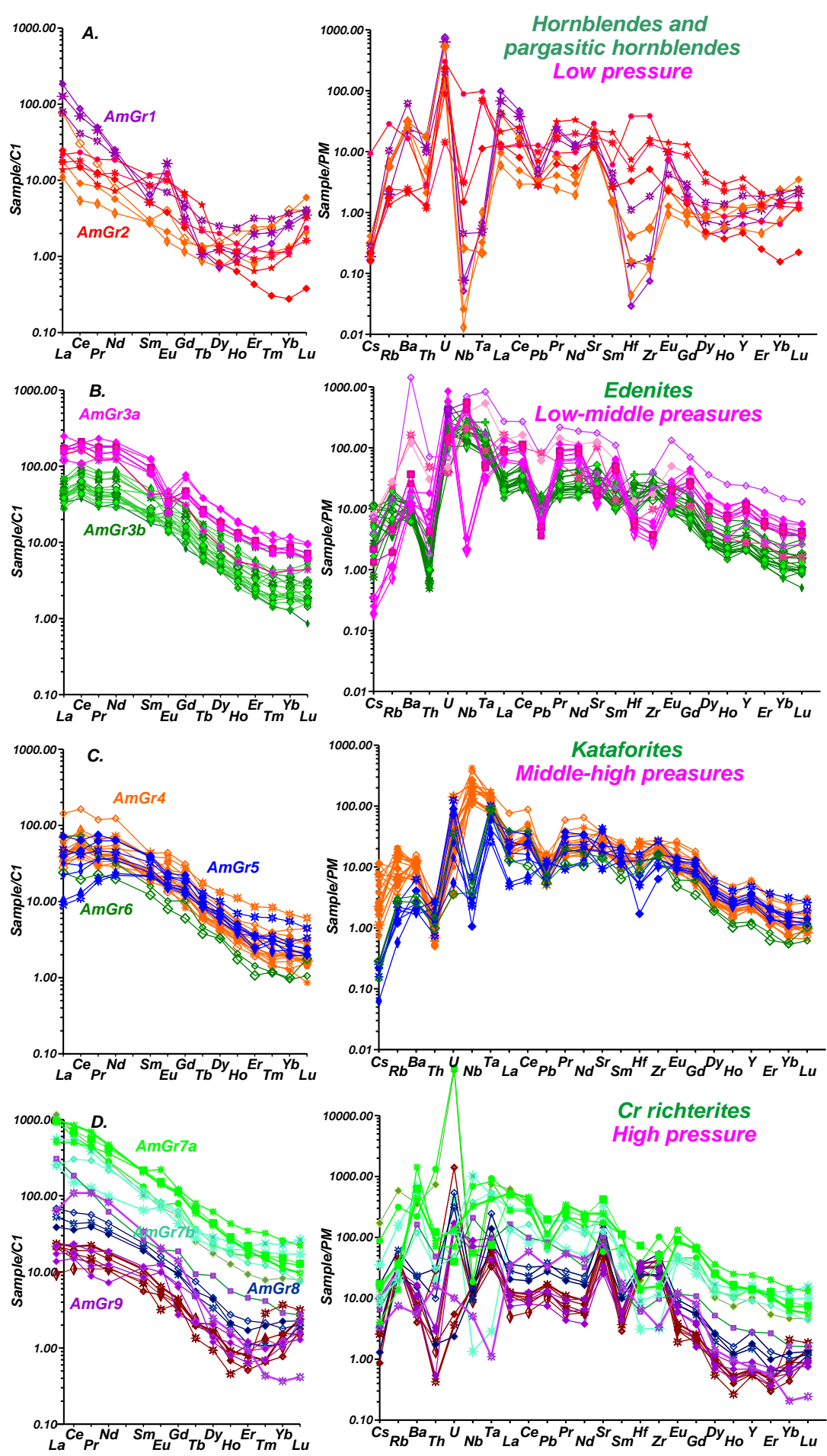

Figure 14. REE patterns and TRE spider diagrams for patterns for amphiboles from Leningrad pipe: a) low-pressure hornblendes and other Ca- amphiboles; b) low-middle-pressure pargasites; c)middle- high - pressure pargasites eddinites; d) high-pressure $\mathrm{Cr}$ - richterites. Normalization is the same as in Figure 11.

The samples from the Gr8Am reveal a highly inclined REE part from $\mathrm{Sm} / \mathrm{Yb} \sim 70-50$ display with the more plattened right and left parts. They have strong $\mathrm{U}, \mathrm{Ta}$, Sr peaks and elevated $\mathrm{Rb}, \mathrm{Hf}, \mathrm{Zr}, \mathrm{Y}$ and minimums in $\mathrm{Nb}$. The more $\mathrm{HT}$ group reveal less enriched in REE and nearly conform patterns. They display the same peaks in $\mathrm{Ba}, \mathrm{U}$ (for most) $\mathrm{Ta}, \mathrm{Sr}$, $\mathrm{Zr}, \mathrm{Hf}$ and small in $\mathrm{Y}$ and negative in Th. One sample shows negative Ta and positive Th anomalies. 


\subsection{Olivine and orthopyroxene}

One Opx show lowered concave downward inclined REE pattern with Lan at 20. The SDTR display deep minima in $\mathrm{Zr}, \mathrm{Hf}, \mathrm{Nb}$ but elevated Th, U, Sr. And one olivine display also inclined concave pattern with the minima from Dy to Tm. The right part of the SDTR is lightly inclined but relatively smooth with the minima at Ta but peaks in $\mathrm{Pb}$.

\section{Discussion}

8.1 The mineralogy as the factor of the diamond grade and geodynamic conditions.

The mineralogy of the Leningrad pipe, in general, is similar to another pipe of the Devonian kimberlites from YKP [70] showing the long range of the $\mathrm{Cr} 2 \mathrm{O} 3-\mathrm{CaO}$ in the lherzolitic field and extending to $18.2 \% \mathrm{Cr} 2 \mathrm{O} 3$ belonging to the harzburgitic field which is one of the highest in the YKP. It suggests the very deep source of this pipe like those from the Mir [67, Nakyn [71] or Zarnitsa [13]. Unfortunately, like some other large pipes including the Zarnitsa, the prevailing breccias capture mainly the upper part of the mantle section without diamonds. The pipe has the poly -phased structure, which is visible not only from the observations of the kimberlite relationships in the pipe but also supported by the complex chromite and ilmenite trends in the variation diagrams. It is possible like in Zarnitsa pipe to find the porphyric macrocrystic kimberlites, which commonly contain more deep-seated materials. The majority of the chromites are rather high chromium that also expands the perspectives of the diamond grade. A rather high amount of the almandine-pyrope garnets that according to the thermobarometry may be diamondiferous. In general the northern parts of the Siberian craton are very perspective for the diamonds because they were discovered in many placers which contain beautiful diamonds [72-74]. But their sources were not found yet. They may belong to kimberlites and lamproites of several stages of activity [1-3]. There are many signs that the mantle in the northern YKP is more hydrated and the quality of diamonds is higher.

\subsection{Comparisons with the amphiboles Worldwide.}

The most interesting feature of the Leningrad pips - the high variations of the Cr-bearing amphiboles, which is the highest in the World among the kimberlitic pipes and any other mantle objects in the World. They cover all the range from the $\mathrm{Cr}$ hornblendes to pargasites, edinites and richterites, which are presented in all PT ranges of the mantle column.

Commonly amphiboles occur in the highly metasomatized mantle peridotites. The richterites were found in the MARID xenoliths in several pipes from the Kaapvaal craton [27, 75-77 ]. The pargasitic types were described in the peridotite mantle xenoliths from Kimberly pipe [82] and in the xenoliths from Gibeon Kimberlite Province, southern Namibia $[79,80]$. They were found in the eclogites of Orapa, Roberts Victor [75] and other kimberlite pipes of South Africa [81]. Ca- amphiboles were found in peridotite of many orogenic massifs such as Lherz [24], etc. They commonly occur in the mantle xenoliths from the alkali basalts in Transbaikal in Bartoy volcanoes [82], in the European Cenozoic basalts including Massif Central [83], Rhon Graben [84] and Pannonian [26], in Victoria Land, Australia [85, 86] in Nushan, China [87] and many mantle arc basalt localities [88] other locations of mantle xenoliths. Commonly the $\mathrm{Cr}$ - bearing amphiboles occurs in the upper part of the SCLM because the stability of the hornblendes and more rare pargasites are restricted by the $3.5 \mathrm{GPa}$ [20]. In addition, the breakdown of the amphiboles in the mantle in the island arc environment is the s main source of the $\mathrm{H} 2 \mathrm{O}$ during the formations of the granites above the deep subduction zones [89]. The amphibole metaso- 
matism put an essential role in the distribution of the LILE and HFSE components in the mantle [90] due to the high partition coefficients of this mineral [90-94]. Nevertheless, the more recent researches show that pargasites are stable to $20.5 \mathrm{GPa}$ [23]. The PT stability field is consistent with the conditions of both hot and cold subduction. The richterites are stable to $8.5 \mathrm{GPa}$ and more $[22,90]$. The stability of the amphiboles is highly dependent on the system. Thus, the potassium-rich fluids, magmas, and systems are expanding the stability of this mineral. The different varieties are regularly distributed in the mantle column according to the temperature field and the magmatic and fluid systems developed in the different parts of the SCLM. The presence of the crust signatures in the geochemical features of the amphibole suggest the strong influence of the subduction material to very high-pressure conditions of the SCLM $[94,96]$. The abundance of the amphibole is caused by the continental margin environment of the W.Ukukit mantle in ancient times.

\subsection{Thermobarometry and mantle layering, the geothermal conditions of the SCLM beneath} West Ukukit field.

The layering of the mantle column is mainly shown by the distribution and variations of the pyrope garnets in the SCLM. In the P-Fe \#, diagrams there are several small arrays of the growth of the Fe with the decreasing pressure which probably refer to the primary layering coursed by the coupling of the paleo subduction slabs in the Archean time [97]. This trend is more intermittent in the middle part from 3 to $4.5 \mathrm{GPa}$. The lithosphere base is probably found at the common position at $6 \mathrm{GPa}$. The hot garnet geotherm is found from 7.5 to $5.5 \mathrm{GPa}$ where the ilmenite trend is produced by interaction with the protokimberlite system. Heating is found in the middle part where there is a hot branch formed by pyropes along the diamond graphite boundary. In the upper part of SCLM, the heating is pronounced from $3 \mathrm{GPa}$ to Moho. However, several clots of rather low-temperature garnets are found at $7 \mathrm{GPa}$.The eclogitic garnet are forming two branches in the PT and P-Fe\# plots. The Fe\# growth during the pressure decrease was probably created seriously during the rise of the melts, which were produced during submerging of the subduction layers to the depth [98,99]. It is proved that even peridotites paleosubducted layers were seriously re-melted [100] and eclogites should be nearly completely melted forming ascending magmatic bodies. On the PT diagram, eclogites are mainly forming the branch corresponding to the $40 \mathrm{mw} / \mathrm{m}^{2}$ in the lower and middle part of the mantle column and they reveal low-temperature conditions in the upper SCLM part starting from $4 \mathrm{GPa}$. Branching is also found for the Cpx geotherm they created the low-temperature branch $35 \mathrm{mw} / \mathrm{m} 2$ and less from 4 to $5.5 \mathrm{GPa}$ but they also trace the heated (advective) branch from 6 to $4 \mathrm{GPa}$ probably due to the influence of the protokimberlite melts and fertilization processes [101]. The most Mg-rich chromite compositions also are distributed in the middle part of the mantle section from 3 to $5 \mathrm{GPa}$. While in the lower and upper parts of the SCLM, they became more Fe rich due to interaction with the protokimberlites. in the lower and middle part and probably with basaltic melts in the upper part of the SCLM The same feature is found for the compositions of the amphiboles which are forming the hot and Fe rich branches in the base of the lithosphere and the upper part starting from $3 \mathrm{GPa}$.

The ilmenite trends and distribution in the mantle column is complicated. The lower part from 7.5 to $6 \mathrm{GPa}$ is rather high-temperature and Mg-rich and corresponds in the PT conditions to the dunite harzburgite garnets. Probably these are the high-temperature metasomatites at the lithosphere base, which are found in most kimberlite pipes. The deviations to the high Mg-Ilm compositions refer to the metasomatites. However, the major trend is the typical trend of the protokimberlite melt fractionation.

The most complex PT conditions give the amphiboles. They are sharply divided into three pressure groups. The lower part is correspondent to the 3 clusters. The sodic rich- 
terites with the $\mathrm{Eu}$ anomalies gives the lowest temperature branches to $35 \mathrm{mw} / \mathrm{m}^{2}$ starts from $6.5 \mathrm{GPa}$ and continuing to $4 \mathrm{GPa}$ slightly heating. The possible model is reactions with rising of the hydrous subduction-related fluid rich melts through the mantle column. The hottest branch is correspondent to the $\mathrm{K}$-richterites and edinites at the lithosphere, which are $\mathrm{Fr}-\mathrm{Ti}$, enriched due to reactions with group II kimberlite and heated to the $45 \mathrm{mw} / \mathrm{m}^{2}$ geotherm. There are all the intermediate temperature variations. Next hot clot the amphiboles is at 5 - 5.5 GP and this cluster nearly coincides with the hot garnet branch for the pyropes. The next heated branch is near the diamond-graphite boundary. The heated branches are most pronounced between 3-1 GPa. In addition, the heating for amphiboles is from 45 to $90 \mathrm{mw} / \mathrm{m} 2$ geotherm in the upper part for both Cpx and Amph that corresponds to typical "basaltic" or SEA geotherm [102]. The behaviour of the Al in amphiboles on the $\mathrm{P}$-Variation diagram (for amphiboles $\mathrm{Al}_{2} \mathrm{O}_{3}$ ) shows the changes from the $\mathrm{LAB}$ level to $3.5 \mathrm{GPa}$ where the $\mathrm{Al}_{2} \mathrm{O}_{3}$ begin essentially grow up. Starting from 2.2, GPa the $\mathrm{Al}$ in amphiboles drastically splits from enriched in al compositions to typical hornblendic with the $10-14$ wt. $\% \mathrm{Al}_{2} \mathrm{O}_{3}$.

Using the Cpx, Gar, Chr, Ilm and Amph composition we determined 7 levels in the mantle column beneath the Leningrad pipe.

8.4 Geochemistry of minerals from mantle peridotites, metasomatites and vein systems and relations to geodynamics.

Garnets are splitting by the REE and TRE spectrums to typical lherzolites with the $\mathrm{Zr}$ - Hf peaks which mark $\mathrm{H}_{2} \mathrm{O}$ metasomatism [66] and two harzburgitic types with the different LREE content and probably melting degrees of host rocks. It is clear that dunitic and harzburgitic garnets with relatively low HFSE should be related to the subduction-related processes which commonly reveal elevated $\mathrm{Ba}, \mathrm{U}, \mathrm{Sr}, \mathrm{Pb}$ [103] but troughs in the HFSE.. Pyroxenitic garnets type 1-2 with the elevated or high levels incompatible elements but minima in Zr, Hf with the high levels in all incompatible elements probably have the hybrid nature of mixed subduction relayed processes. Garnets from the low crust probably refer to the cumulates from the plume basalts.

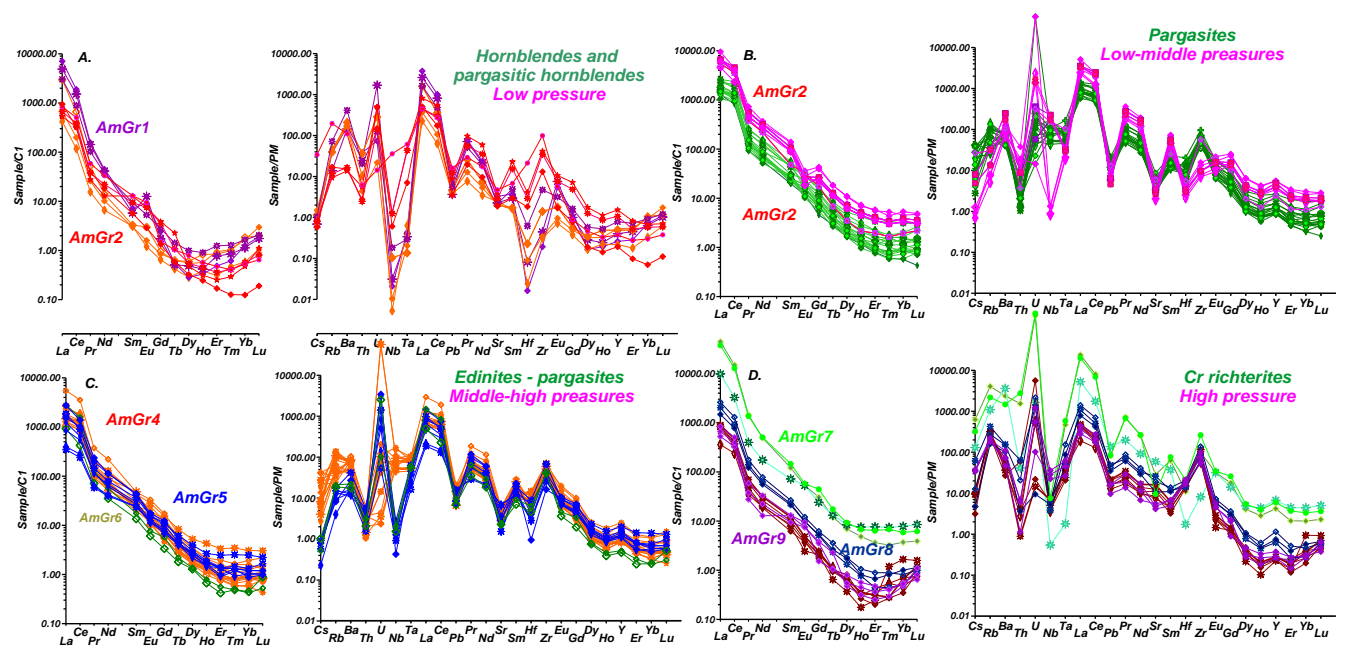

Figure 14. REE patterns and TRE spider diagrams patterns for melts in equilibrium with the amphiboles from the Leningrad pipe. Partition coefficients [91, 92,104] Normalization is the same as in Figure 11.

The clinopyroxenes quite variable tendencies. One Cpx from Sp lherzolites demonstrate high Th-U peaks typical of carbonatitic melts [105] but the other with. The Cpx from garnet facies also reveals controversial tendencies. Two of them have elevated $\mathrm{Rb}$ and $\mathrm{Sr}$, elevated $\mathrm{Th}$ but low $\mathrm{U}$ what probably means the influence of potassium bearing 
fluids. The trough in $\mathrm{Zr}$ and $\mathrm{Hf}$ combines with the strange $\mathrm{Sr}$ peak for olivine. These features are suggesting the influence of the evolved carbonatite melts Gr1, Gr5. The typical

The clinopyroxenes with the high REE level and Th, U, Sr Gr1Cpx, Gr3 Cpx, Gr5 Cpx probably are related to the alkali-carbonatitic melt. Gr4- should relate to early-stage protokimberlitic melts and Gr4Cpx have mixed signatures. The inclination is commonly regulated by the $\mathrm{Cpx} / \mathrm{Gar}$ ratios in the source which is higher for the pyroxenites,

Most of the low-pressure hornblendic amphiboles show concave REE patterns have the concave downward patterns which mean the fluid type crystallization as it is found for the boninites and anomalies of Eu suggesting the participation of Pl bearing crust material in the source of fluids. They could be created from the amphibolization for the pre-existing eclogites or directly due to the substitution of the rutiles [103]. The lowmiddle-pressure amphiboles reveal rather high La/Ybn ratios which suggest the crystallization in presence of garnets or/ and participation of the LREE rich fluids in the origin of the parental melts. High $\mathrm{Ba}$ and elevated $\mathrm{U}$ and essentially high $\mathrm{Na} / \mathrm{K}$ ratios support the presence of Na- subduction-related fluids [95] as well as the very deep HFSE anomalies with the varying $\mathrm{Ta}-\mathrm{Nb}$ which is typical for the rutiles having different partition coefficients for the $\mathrm{Nb}$ and $\mathrm{Ta}$ [103]. The edinites and pargasites from the middle-pressure interval reveal the serious difference in the geochemistry. The edinites from the low-temperature branch have minima in $\mathrm{Eu}$, which suggest the higher oxidation stage they have higher $\mathrm{Rb}, \mathrm{Ba} \mathrm{T}$ and reveal minima in $\mathrm{Zr} \mathrm{Hf}$ and $\mathrm{Nb}$ but elevated Ta. The pargasites demonstrate the lower REE and TRE values and practically no Eu and HFSE anomalies and even peak in Ta and as well lower $\mathrm{Ba}$, Th, $\mathrm{U}$ than pargasites and high $\mathrm{Sr}$ and $\mathrm{Pb}$. This probably meant the participation of the rather high temperature melts in their origin because the higher the temperature the low are the REE and as well $(\mathrm{La} / \mathrm{Yb}) \mathrm{n}$ ratios The fan-like spreading REE part of the patterns suggest the participation of the partial melts from the peridotite source with the different $\mathrm{Ga} / \mathrm{Cpx}$ rations in the source [37]. The most high-pressure richterites are very different. Those with high REE and inclination $(\mathrm{La} / \mathrm{Yb}) \mathrm{n}$, LILE and all other incompatible components and minimum in Ta suggest low degree melting and high $\mathrm{Ga} / \mathrm{Cpx}$ ratio in the substrate [66].

The melts reconstructed with the KD for the amphiboles [91, 92,105] reveal very high LREE patterns and concave in the MREE part (Figure 13). The levels of the HFSE are mostly low but there are some varieties rather high in $\mathrm{Zr}$ which is probably evidence about the participation of the $\mathrm{H}_{2} \mathrm{O}$ rich melts/fluids in their generation. They are not close to boninites but somewhat similar [20]. Most probably such amphiboles generation maters were fluids.

The halogens of the amphiboles of all types are represented only by chlorine which supported the idea of the influence of the subducted related fluids $[108,109]$. Because the fluorine is more compatible in Ca- amphiboles than chlorine [109]. The abundance of sulphides, apatites, barite also support this idea.

8.5 Model of the mantle evolution of the SCLM beneath the Ukukit field and the role of the subduction.

The SCLM beneath Ukukit have rater contrast layering typical of Siberian Craton [66] and The formation of the mantle beneath the Ukukit field is not different from the central parts of the craton. The model suggests the hot subduction at the presence of superplume which caused the floating of essentially melted peridotite - eclogite slab and joining it to craton keel from beneath [97]. The alternative model suggests the stacked subducted slabs [66]. 
The essential difference is the broad development of amphiboles, which means the later very vast interaction with the subducted related melts, which were enriched in the LILE and sometimes U, Th, HFSE due to participation of the continental material in the subducted material. It is difficult to imagine the abundance of primary amphiboles in essentially heated Early Archean mantle. The contrasting behaviour of $\mathrm{Ta}$ and $\mathrm{Nb}$ is regulated by the rutile partition coefficients likely for primary eclogites. Though it could occur because they were found in the Archean mantle eclogites [110]. And it was suggested they were the source of the archean crust [111]. But mostly metasomatized eclogites are related to later events [113]. The hydrated mantle may occur in the continental arc environment where $\mathrm{H}_{2} \mathrm{O}$ together with $\mathrm{Cl}, \mathrm{S}, \mathrm{P}$ could provide essentially influence the primary mantle peridotites and eclogites [112]. The subduction-related fluids passed through the all mantle column and caused vast perturbations. Subduction and $\mathrm{Na}$ and $\mathrm{K}$ (siliceous) types of fluids percolated through the mantle with abundant eclogites causing amphibolization at the different levels of the mantle column. The plumes produced hybridism and more smooth patterns. The presence of the different types of amphibole suggests that it was subjected to multistage fluid interaction of both $\mathrm{Na}$ and essentially type which suggests the changes of the type of subduction processes. The HT amphiboles appeared as a result of the interaction of the hydrated mantle with the plumes in several stages. The huge compositional variation amphiboles from the Leningrad pipe nearly cover all types of mantle amphiboles [13]. The pressure interval for the amphiboles nearly covers all types of mantle amphiboles determined for the new version of the amphibole thermobarometry [51] (see appendix)support the experimental data [115-126] and presence of amphiboles in diamond inclusions [127] and deepest metasomatites $[128,129]$. The presence of the mica and amphiboles also determine the composition of the many types of mantle melts [119] including basalts and lamproites.

\section{Conclusions}

1. Leningrad pipe contains a huge number ( $>500$ EPMA analyses) of various amphiboles (9 groups according to geochemistry) which reveal the variations from $\mathrm{Cr}$ - pargasitic hornblendes through $\mathrm{Cr}$ - pargasites, eddinites, kataforites to $\mathrm{Cr}$ - richterites referring to the different PT conditions from lithosphere base to the Moho. This suggests high H2O activity in the mantle column and the relatively low-temperature nature of mantle metasomatites.

2. The geochemistry reveals the vast variations of the TRE and REE spectra. The low-pressure $\mathrm{Cr}$ - pargasites have the signs of fluid interaction with concave REE patterns and peaks of $\mathrm{Ba}$, HFSE minima reflecting high oxygen fugacity. The anomalies of Eu suggests the crust material participation. The HFSE enrichment possibly suggests the interactions with the evolved essentially carbonatitic plume mostly protokimberlite melts.

4. The chemistry of pyropes suggests the very deep level of the xenogenic material capture 18 wt. \% Cr2O3 pyropes suggesting the deep probably asthenospheric origin.

5. The mantle beneath Leningrad and nearby pipes show a high amount of the sub-Ca garnets suggesting the relatively high diamond grade.

6. Complex geotherms and trends of amphiboles, chromites and ilmenites and variable geochemistry of minerals suggests the multistage interaction with the subduction-related and later plume melts.

Supplementary Materials: The following are available online at www.mdpi.com/xxx/s1, 
Author Contributions: Conceptualization, I.A.; methodology I.A., S.B., O.O. and N.M.; software, I.A.; validation, I.A., S.B., O.O, N.M.; formal analysis, I.A., S.B. and N.M; investigation, I.A., S.B., O.O, N.M; resources, I.A.; data curation, I.A., S.B., O.O. and N.M.; writing-original draft preparation, I.A..; writing - review and editing, I.A.; visualization, I.A.; supervision, I.A., O.O.,; project administration, I.A.; funding acquisition, I.A. All authors have read and agreed to the published version of the manuscript.

Funding: This research was funded by Supported by RFBR grants 19-05-00788,. Work was done on state assignment of IGM SB RAS, governmental assignment in terms of Project IX.129.1.4. The research was supported by the Ministry of Science and Higher Education of the Russian Federation, N 121031700315-2.

Data Availability Statement: Ithe data fr Siberian craton and many of published paper may be found in Research Gate https://www.researchgate.net/profile/Igor-Ashchepkov

Acknowledgements: We are grateful to N.S.Karmanov and the stuff of electronic laboratory of the IGM SB RAS.

Conflicts of Interest: The authors declare no conflict of interest.

\section{Appendix A. Amphibole thermobarometer equations.}

\section{Barometer}

$\left.\left.\mathrm{XFe} 3 \mathrm{am}=\mathrm{Fe}+\mathrm{Mn}+\mathrm{Mg}+\mathrm{Ca}-4 ; \quad \mathrm{xAMKd}=\mathrm{Si}^{* *} 1 /\left(\mathrm{Al}+\mathrm{XFe} 3 \mathrm{am}+2^{*} \mathrm{Ti}\right)\right)^{* *} 0.75^{*}(\mathrm{Na}+\mathrm{K})\right) / \mathrm{Ca}$;

$\left.\mathrm{P}=0.0575^{*}\left(4+\left(\mathrm{K} /(\mathrm{Na}+\mathrm{K})^{*} 1.5^{*} \mathrm{Mg}\right) / \mathrm{Fe}+4.25^{*}\left(0.85^{*} \mathrm{Na}+1.10^{*} \mathrm{~K}\right) / \mathrm{Ca}\right)\right)^{*} \times \mathrm{xaMD}^{*} \mathrm{ToK}^{* *} 0.75 /\left(1+7^{*}\right.$

$\left.\left.\mathrm{Fe})-\mathrm{Ln}(1273 /(\mathrm{ToK}))^{*} 2.5^{*}\left(3.8^{*} \mathrm{Mg}-\mathrm{Al}^{*} 2.3\right)+3^{*} \mathrm{Ti}\right) !+12^{*} \mathrm{Cr}+2^{*} \mathrm{~K}\right)+25-0.04^{*} \mathrm{Ti}^{*} \mathrm{ToK}-\mathrm{Ca}{ }^{*}(\mathrm{ToK}-750)$ /300; $\mathrm{P}=\mathrm{P}^{*} 0.9+5+1.55^{*} \mathrm{Ti}$

Thermometer. Ravna, 2000 Gar-Amphibole (monomineral version)

CaGar $=0.1958^{*} \mathrm{CaAm}+0.1889 ; \mathrm{MgGar}=0.475^{*} \mathrm{MgAm}-0.5753+0.0035^{*} \mathrm{P} ;$ FeGar $=1.125^{*}$ FeAm-0.1132-0.0001*P

$\mathrm{Z}=\mathrm{Ca} \mathrm{Fe}+\mathrm{Mg} ;$ FeGar=FeGar*3/Z; MgGar = MgGar *3/Zl CaGar = CaGar*3/Z; x581=Ca/3; x561=Mn/3

$\mathrm{xKD}=(\mathrm{Fe} / \mathrm{Mg}) \operatorname{Gar}^{*}(\mathrm{Mg} / \mathrm{Fe}) \mathrm{Am}$

$\mathrm{T}=\left(1504+1784^{*}(x 581+x 561)\right) /(\operatorname{Ln}(x K D)+0.720)$

Corrections: $\mathrm{T}=\mathrm{T}-(52-\mathrm{SiO} 2))^{*} 35+50+5^{*} \mathrm{Ti} ; \mathrm{T}=\mathrm{T}+(\mathrm{P}-50)^{*} 2.5-20$

Where $\mathrm{P}$ - pressure in kbar; $\mathrm{T}-\mathrm{ToK}$.

The method is realized in the PT program written in FORTRAN 77 (Ashchepkov, 2011).

The results of the calibration and the correlations of the calculations with the experimental values are represented on the diagram (Figure 10).

\section{References}

1. Kostrovitsky, S.I.; Morikiyo, T.; Serov, I.V.; Yakovlev, D.A.; Amirzhanov, A.A. Isotope-geochemical systematics of kimberlites and related rocks from the Siberian Platform. Russian Geology and Geophysics 2007, 48, 272-290.

2. Sobolev, N.V.; Sobolev A.V.; Tomilenko, A.A.; Kuz'min, D.V.; Grakhanov, S.A.; Batanova, V.G.; Logvinova, A.M.; Bul'bak, T.A.; Kostrovitskii, S.I.: Yakovlev, D.A.: Fedorova, E.N.; Anastasenko, G.F.; Nikolenko, E.I.; Tolstov, A.V.; Reutskii V.N. Pro- 
spects of search for diamondiferous kimberlites in the northeastern Siberian Platform. Russian Geology and Geophysics 2018, 59, 1365-1379.

3. Sun, J.; Liu, C.-Z., Tappe, S.; Kostrovitsky, S.; Yang, J.-H., Repeated kimberlite magmatism beneath Yakutia and its relationship to Siberian flood volcanism: Insights from in situ $\mathrm{U}-\mathrm{Pb}$ and $\mathrm{Sr}-\mathrm{Nd}$ perovskite isotope analysis. Earth and Planetary Science Letters 2014, 404, 283-295.

4. Sun, J.; Tappe, S.; Kostrovitsky, S.I.; Liu, C.-Z.; Skuzovatov, S.Yu.; Wu, F.-Yu. Mantle sources of kimberlites through time: A $\mathrm{U}-\mathrm{Pb}$ and Lu-Hf isotope study of zircon megacrysts from the Siberian diamond fields. Chemical Geology 2018, 479, $228-240$.

5. Zaitsev, A. I., Smelov, A. P. Isotopic geochronology of rocks of the kimberlite formation of the Yakut province. Institute of diamond and precious metals Geology SB RAS. 2010, 105 p.

6. Ukhanov, A.V.; Khachatryan, G.K. 2011. Diamonds from the Poiskovaya, Zapolyarnaya, and Leningrad Kimberlite Pipes, Northern Yakutia: Correlation of CarbonIsotopic Composition and Nitrogen Content As an Indicator of Fluid Diamond Formation. Geology of Ore Deposits 2011, 53(8), 783-791.

7. Kornilova V. P.; Spetsius Z.V., Pomazanskiy B.S. 2016. Petrographic-mineralogical peculiarities and feasibility of kimberlite pipes Lorik and Svetlana diamond grade re-estimation (West Ukukit field, Yakutia). Regional geology and metallogeny 2016, 68, 92-99.

8. Afanasyev, V.P.; Agashev, A.M.; Orihashi, Y.; Pokhilenko, N.P.; Sobolev, N.V. Paleozoic U-Pb Age of Rutile Inclusions in Diamonds of the V-VII Variety from Placers of the Northeast Siberian Platform. Doklady Earth Sciences 2009, 428, 1151-115.

9. Khmel'kov, A. M. Major minerals of kimberlites and evolution in the process of creation of their lateral areals (example, the Yakutian diamondiferous province). Novosibirsk: ART, 2008, 252 p. (in Russian.)

10. Ashchepkov, I.V.; Logvinova, A.M.; Reimers, L.F.; Ntaflos, T.; Spetsius, Z.V.; Vladykin, N.V.; Downes, H.; Yudin, D.S.; Travin, A.V.; Makovchuk, I.V.; Palesskiy, V.S.; Khmel'nikova, O.S. The Sytykanskaya kimberlite pipe: Evidence from deep-seated xenoliths and xenocrysts for the evolution of the mantle beneath Alakit, Yakutia, Russia. Geoscience Frontiers 2015, 6, 687-714.

11. Ashchepkov, I.V.; Logvinova, A.M.; Ntaflos, T.; Medvedev, N.S.; Downes, H. Alakit and Daldyn kimberlite fields, Siberia, Russia: Two types of mantle sub-terranes beneath central Yakutia? Geoscience Frontiers 2017, 8(4), pp. 671-692.

12. Ashchepkov, I.V.; Ntaflos, T.; Kuligin, S.S.; Malygina, E.V.; Agashev, A.M.; Logvinova, A.M.; Mityukhin, S.I.; Alymova, N.V.; Vladykin, N.V.; Palessky, S.V.; Khmelnikova, O.S. Deep-Seated Xenoliths from the Brown Breccia of the Udachnaya Pipe, Siberia. D. G. Pearson et al. (eds.). Proceedings of 10th International Kimberlite Conference. - New Delhi: Springer India 2013, v. 1. p, 59-74.

13. Ashchepkov, I.; Medvedev, N.; Ivanov, A.; Vladykin, N.; Ntaflos, T.; Downes, H.; Saprykin, A.; Tolstov,A.; Vavilov, M.; Shmarov, G. Deep mantle roots of the Zarnitsa kimberlite pipe, Siberian craton, Russia: Evidence for multistage polybaric interaction with mantle melts. Journal of Asian Earth Sciences 2021, 213, 104756.

14. Ashchepkov, I.V.; Ntaflos, T.; Spetsius, Z.V.; Salikhov, R.F.; Downes, H. Interaction between protokimberlite melts and mantle lithosphere: Evidence from mantle xenoliths from the Dalnyaya kimberlite pipe, Yakutia (Russia). Geoscience Frontiers 2017, $8(4), 693-710$.

15. Solov'eva, L.V.; Kalashnikova, T.V.; Kostrovitsky, S.I.; Ivanov, A.V.; Matsuk, S.S.; Suvorova, L.F. Phlogopite and phlogopite-amphibole parageneses in the lithospheric mantle of the Birekte terrane (Siberian craton). Dokl. Earth Sc. 2017, 475, $822-827$.

16. Sun, J.; Rudnick, R.L.; Kostrovitsky, S.; Kalashnikova, T.; Kitajima, K.; Li, R.; Shu, Q. The origin of low-MgO eclogite xenoliths from Obnazhennaya kimberlite, Siberian craton. Contrib. Mineral. Petrol. 2020, 175, 25.

17. Ridolfi, F.; Renzulli, A. Calcic amphiboles in calc-alkaline and alkaline magmas: thermobarometric and chemometric empirical equations valid up to $1,130^{\circ} \mathrm{C}$ and $2.2 \mathrm{GPa}$. Contrib. Mineral. Petrol. 2012, 163, 877-895.

18. Putirka K. Amphibole thermometers and barometers for igneous systems and some implications for eruption mechanisms of felsic magmas at arc volcanoes. American Mineralogist 2016, 101, 841-858

19. Simakin, A.G.; Shaposhnikova O.Yu. Novel amphibole geobarometer for high-magnesium andesite and basalt magmas. Petrology 2017, 25, 226-240

20. Niida, K.; Green, D. H. Stability and chemical composition of pargasitic amphibole in MORB pyrolite under upper mantle conditions. Contrib. Mineral. Petrol. 1999, 135, 18-40.

21. Pirard, C., Hermann, J. Experimentally determined stability of alkali amphibole in metasomatised dunite at sub-arc pressures. Contrib. Mineral. Petrol. 2015, 169, 1.

22. Konzett, J., Sweeney, R., Thompson, A.B., Ulmer, P. Potassium amphibole stability in the upper mantle: an experimental study in a peralkaline KNCMASH system to $8.5 \mathrm{GPa}$. J. Petrol. 1997, 38 (5), 537-568.

23. Comboni, D.; Lotti, P.; Gatta, G.D.; Merlini, M.; Liermann, H.-P.; Frost, D.J. Pargasite at high pressure and temperature. Physics and Chemistry of Minerals 2018, 45, 259-278.

24. Marocchi, M.; Hermann, J.;Tropper, P.; Bargossi, G.M.; Mair, V. Amphibole and phlogopite in "hybrid" metasomatic bands monitor trace element transfer at the interface between felsic and ultramafic rocks (Eastern Alps, Italy). Lithos 2010, 117, $135-148$.

25. Tedonkenfack, S.S.T.; Puziewicz, J.; Aulbach, S.; Ntaflos, T.; Kaczmarek,M.-A.; Matusiak-Małek M.; Kukuła A.; Ziobro M.. Lithospheric mantle refertilization by DMM-derived melts beneath the Cameroon Volcanic Line-a case study of the Befang xenolith suite (Oku Volcanic Group, Cameroon). Contrib. Mineral. Petrol. 2021, 176, 37.

26. Matusiak-Malek, M.; Puziewicz, J.; Ntaflos, T.; Grégoire, M.; Kukula, A.; Wojtulek P.M. Origin and evolution of rare amphibole-bearing mantle peridotites from WilczaGóra (SW Poland), Central Europe. Lithos 2017, 286-287,. 302-323. 
27. Giuliani, A.; Fiorentini, M.L.; Martin, L.A.J.; Farquhar, J.; Phillips, D.; Griffin,W.L.; LaFlamme, C. Sulfur isotope composition of metasomatised mantle xenoliths from the Bultfontein kimberlite (Kimberley, South Africa): contribution from subducted sediments and the effect of sulfide alteration on S isotope systematics. Earth Planet. Sci. Lett. 2016, 445, 114-124.

28. Babushkina S.A. Mantle phlogopites from Leningrad pipe (from Breccia with a Massive Texture).Vestnik of the NEFU. Earth Science series 2018, 4 (12), 14-19.

29. Bulanova, G.P.; Barashkov, Yu.P.; Tal'nikova, S.B.; Smelova, G.B. Prirodnyi almaz-geneticheskie aspekty (Natural Diamond: Genetic Aspects), Novosibirsk: Nauka, 1993. 215p

30. Pearson D.G.; Shirey S.B.; Carlson R.W.; Boyd F.R.; Pokhilenko N.P.; Shimizu N. Re-Os, Sm-Nd and Rb-Sr isotope evidence for thick Archaean lithospheric mantle beneath the Siberia craton modified by multi-stage metasomatism. Geochim. Cosmochim. Acta. 1995, 59, 959-977

31. Griffin, W.L.; Ryan, C.G.; Kaminsky, F.V.; O'Reilly, S.Y.; Natapov, L.M.; Win, T.T.; Kinny, P.D.; Ilupin, I.P. The Siberian lithosphere traverse: mantle terranes and the assembly of the Siberian Craton. Tectonophysics 1999, 310, 1-35.

32. Ashchepkov, I., V; Vladykin, N. V.; Kalashnyk, H. A.; Medvedev, N. S.; Saprykin, A., I; Downes, H.; Khmelnikova, O. S. Incompatible element-enriched mantle lithosphere beneath kimberlitic pipes in Priazovie, Ukrainian shield: volatile-enriched focused melt flow and connection to mature crust? International Geology Review 2020, 63, 1-22

33. Shumlyanskyy L.V.; Kamenetsky V.S.; Tsymbal S.M.; Wilde S.A.; Nemchin A.A.; Ernst R.E.; Shumlianska L.O. Zircon megacrysts from Devonian kimberlites of the Azov Domain, Eastern part of the Ukrainian Shield: Implications for the origin and evolution of kimberlite melts. Lithos 2021, 406-407, 106528.

34. Tsymbal, S.N., Kremenetsky, A.A., Sobolev, V.B. Tsymbal, Yu.S. Zirconium minerals from kimberlites of Novolaspinskaya pipe and dike (south-east of the Ukrainian shield). Mineralogical Journal (Ukraine) 2011, 33, 41-62.

35. Lavrent'ev Y.G., Korolyuk V., Usova L. and Nigmatulina. E. Electron probe microanalysis of rock-forming minerals with a JXA-8100 electron probe microanalyzer. Russian Geology and Geophysics 2015, 56, 1428-1436.

36. Lavrent'ev, Yu.G.; Karmanov, N.S., Usova, L.V.Electron probe microanalysis of minerals: microanalyzer or scanning electron microscope? Russian Geology and Geophysics 2015, 56 1154-1161.

37. Ashchepkov I.V.; Andre L.; Downes H.; Belyatsky B.A. Pyroxenites and megacrysts from Vitim picrite-basalts (Russia): Polybaric fractionation of rising melts in the mantle? Journal of Asian Earth Sciences 2011, 42, 14-37

38. Sobolev, N.V.; Lavrentev, Y.G.; Pokhilenko, N.P.; Usova, L.V. Chrome-Rich Garnets from the Kimberlites of Yakutia and Their Parageneses. Contributions to Mineralogy and Petrology 1973, 40, 39-52.

39. Dawson J. B. Kimberlites and their xenoliths. Springer-Verlag, Berlin 1980, 252p.

40. Leake, B.E.; Woolley, A.R.; Arps, C.E.S.; Birch, W.D. Nomenclature of amphiboles: Report of the subcommittee on amphiboles of the international association, commission on new minerals and mineral names. American Mineralogist 1997, 82, $1019-1037$.

41. Locock, L. J. An Excel spreadsheet to classify chemical analyses of amphiboles following the IMA recommendations. Computers $\mathcal{E}$ Geosciences 2014, 62, 1-11.

42. Wyatt, B.A.; Baumgartner, M.; Anckar, E.; Grutter, H. Compositional classification of "kimberlitic" and "non-kimberlitic" ilmenite. Lithos 2004, 77, 819-840.

43. Ashchepkov I. V. ; Alymova N. V.; Logvinova A. M.; Vladykin N. V.; Kuligin S. S.; Mityukhin S. I.; Downes H.; Stegnitsky Yu. B.; Prokopiev S.A.; Salikhov R.F.; Palessky V. S.; Khmel'nikova O. S. Picroilmenites in Yakutian kimberlites: variations and genetic models. Solid Earth 2014, 5, 915-938. www.solid-earth.net/5/915/2014/ doi:10.5194/se-5-915-2014

44. Ashchepkov, I.V.; Ntaflos, T.; Logvinova, A.M.; Spetsius, Z.V.; Downes, H.; Vladykin, N.V. Monomineral universal clinopyroxene and garnet barometers for peridotitic, eclogitic and basaltic systems. Geoscience Frontiers 2017, 8, 775-795.

45. Ashchepkov I.V. Empirical garnet thermobarometer for mantle peridotites. Russian Geology and Geophysics 2006, 47 (10), 1071-1085

46. Ashchepkov, I.V.; Pokhilenko, N.P.; Vladykin, N.V.; Logvinova, A.M.; Kostrovitsky, S.I.; Afanasiev, V.P.; Pokhilenko, L.N.; Kuligin, S.S.; Malygina, L.V.; Alymova, N.V.; Khmelnikova, O.S.; Palessky, S.V.; Nikolaeva, I.V.; Karpenko, M.A.; Stegnitsky, Y.B. Structure and evolution of the lithospheric mantle beneath Siberian craton, thermobarometric study. Tectonophysics 2010, 485, 17-41.

47. Taylor, W.R.; Kammerman, M.; Hamilton, R. New thermometer and oxygen fugacity sensor calibrations for ilmenite and chromium spinel-bearing peridotitic assemblages. 7th International Kimberlite Conference. Extended abstracts. Cape Town. 1998, 891-901.

48. Gudmundsson, G.; Wood, B.J. Experimental tests of garnet peridotite oxygen barometry. Contributions to Mineralogy and Petrology 1995, 119, 56-67.

49. Ashchepkov, I.V.; Rotman, A.Y.; Somov, S.V.; Afanasiev, V.P.; Downes, H.; Logvinova, A.M.; Nossyko, S.; Shimupi, J.; Palessky, S.V.; Khmelnikova, O.S.; Vladykin, N.V. Composition and thermal structure of the lithospheric mantle beneath kimberlite pipes from the Catoca cluster, Angola. Tectonophysics 2012, 530-531, 128-15

50. Ashchepkov I.V. 2011. Program of the mantle thermometers and barometers: usage for reconstructions and calibration of PT methods. Vestnik Otdelenia nauk o Zemle RAN 2011, 3, NZ6008, doi:10.2205/2011NZ000138, 2011

51. Ashchepkov I. Universal single grain amphibole thermobarometer for mantle rocks-preliminary calibration. EGU General Assembly Conference Abstracts 2017, 3889

52. Ravna E.K., 2000. Distribution of Fe2+ and Mg between coexisting garnet and hornblende in synthetic and natural systems: an empirical calibration of the garnet-hornblende Fe-Mg geothermometer. Lithos 2000, 53(3-4), 265-277 
53. Brey, G.P., Kohler, T. Geothermobarometry in four-phase lherzolites. II. New thermobarometers, and practical assessment of existing thermobarometers. J. Petrol. 1990, 31, 1353-1378.

54. McGregor, I.D. The system MgO-SiO2-Al2O3: solubility of $\mathrm{Al} 2 \mathrm{O} 3$ in enstatite for spinel and garnet peridotite compositions. .Am. Miner. 1974, 59, 110-119

55. Nimis, P.; Taylor, W. Single clinopyroxene thermobarometry for garnet peridotites. Part I. Calibration and testing of a Cr-in-Cpx barometer and an enstatite-in-Cpx thermometer. Contributions to Mineralogy and Petrology 2000, 139, 541-554.

56. O'Neill, H. St. C.; Wood B.J. An experimental study of Fe-Mg- partitioning between garnet and olivine and its calibration as a geothermometer. Contributions to Mineralogy and Petrology 1979, 70, 59-70.

57. O'Neill, H.St.C.; Wall, V.J. The olivine orthopyroxene-spinel oxygen geobarometer, the nickel precipitation curve, and the oxygen fugacity of the Earth's upper mantle. Journal of Petrology 1987, 8, 1169-1191.

58. Krogh, E.J. The garnet-clinopyroxene Fe-Mg geothermometer - a reinterpretation of existing experimental data. Contrib. Mineral. Petrol. 1988, 99, 44-48.

59. Kennedy, C.S.; Kennedy, G.C. The equilibrium boundary between graphite and diamond. J. Geophys. Res., 1976. 81, 2467-2470.

60. Day, H.W. A revised diamond-graphite transition curve. American Mineralogist 2012, 97, 52-65.

61. Pollack, H.N.; Chapman, D.S., On the regional variation of heat flow, geotherms and lithospheric thickness. Tectonophysics 1977, 38, 279- 296.

62. Stagno, V.; Frost, D.J. Carbon speciation in the asthenosphere: experimental measurements of the redox conditions at which carbonate - bearing melts coexist with graphite or diamond in peridotite assemblages. Earth Planet. Sci. Lett. 2010, 300, 72-84.

63. Stagno, V.; Ojwang, D.O.; McCammon, C.A.; Frost, D.J. The oxidation state of the mantle and the extraction of carbon from Earth's interior. Nature 2013, 493, 84-88.

64. Ashchepkov, I.V., Logvinova, A.M., Spetius, Z.V. Thermobarometry of Inclusions: Implications to the Structure of Lithospheric Mantle and Evolution in Time and Diamond Formation. Acta Geologica Sinica-English Edition 2021, 95 (S1), $18-21$.

65. McCammon, C.A.; Griffin, W.L.; Shee, S.R.; O'Neill, H.S.C. Oxidation during metasomatism in ultramafic xenoliths from the Wesselton kimberlite, South Africa: implications for the survival of diamond. Contrib. Mineral. Petrol. 2001, 141, $287-296$.

66. Ashchepkov, I.V.; Vladykin, N.N.; Ntaflos, T.; Kostrovitsky, S.I.; Prokopiev, S.A.; Downes, H.; Smelov, A.P.; Agashev, A.M.; Logvinova, A.M.; Kuligin, S.S.; Tychkov, N.S.; Salikhov, R.F.; Stegnitsky, Yu.B.; Alymova, N.V.; Vavilova, M.A.; Minin, V.A.; Babushkina, S.A.; Ovchinnikov, Yu.I.; Karpenko, M.A.; Tolstov, A.V.; Shmarov, G.P. Layering of the lithospheric mantle beneath the Siberian Craton: Modeling using thermobarometry of mantle xenolith and xenocrysts. Tectonophysics 2014, 634, 55-75.

67. Evensen, N.M., Hamilton, P.J. Onions, R.K. Rare-earth abundances in chondritic meteorites. Geochimica et Cosmochimica Acta 42, 1979, 1199-1212.

68. McDonough, W.F., Sun, S.- S. The composition of the Earth. Chemical Geology 1995, 120, $223-253$.

69. Griffin, W.L., O'Reilly, S.Y., Abe, N., Aulbach, S., Davies, R.M., Pearson, N.J., Doyle, B.J., Kivi, K. The origin and evolution of the Archean lithospheric mantle. Precambrian Research 2003, 127, 19-41.

70. Sobolev, N.V. Deep-Seated Inclusions in Kimberlites and the Problem of the Composition of the Mantle. Amer. Geophys. Union, Washington, DC. 1974, 279 p.

71. Pokhilenko, N.P.; Sobolev, N.V.; Agashev, A.M.; Vavilov, M.A.; Pokhilenko, L.N.; Malygina, L.N. Anomalous kimberlites of the Snap Lake Area, Canada, and Nakyn Field, Yakutia: evidence of abnormal character of mantle sources and lithosphere structure. Experiment in Geosciences 2002, 10, 143-146.

72. Shatsky, V.S., Zedgenizov, D.A., Ragozin, A.L., Kalinina, V.V. 2015. Diamondiferous subcontinental lithospheric mantle of the northeastern Si-berian Craton: Evidence from mineral inclusions in alluvial diamonds. Gondwana Research 28, $106-120$.

73. Grakhanov, S.A., Malanin, Yu.A., Pavlov V.I., Afanas'ev, V.P., Pokhilenko, N.P., Gerasimchuk, A.V., Lipashova, A.N. 2010. Rhaetian diamond placers in Siberia Russian Geology and Geophysics 51, 127-135

74. Grakhanov A. S., Zarubin R. A., Bogush I. N., Yadrenkin A. B. discovery of upper Triassic diamond Placers in the Olenek Bay of the Laptev sea. OtechestvennayaGeologia. 2009. №1, 53-61.

75. Dawson, J.B., Smith, J.V.1977. The MARID (mica-amphibole-rutile-ilmenite-diopside) suite of xenoliths in kimberlite. Geochim. Cosmochim. Acta 1977, 41, 309-323.

76. Banerjee, S. Kyser, T. K. Mitchel R.H. Oxygen and hydrogen isotopic composition of phlogopites and amphiboles in diamond-bearing kimberlite hosted MARID xenoliths: Constraints on fluid-rock interaction and recycled crustal material in the deep continental lithospheric mantle. Chemical Geology 2018, 47920, 272-285

77. Fitzpayne, A., Giuliani, A., Hergt,J., Phillips, D., Janney, P. New geochemical constraints on the origins of MARID and PIC rocks: implications for mantle metasomatism and alkaline magmatism. Lithos 2018, 318-319, 478-493

78. Simon, N.S.C., Carlson, R.W., Pearson, D.G., Davies G.R. The origin and evolution of the Kaapvaal cratonic lithospheric mantle. Journal of Petrology 2007, 48, 589-625

79. Franz, L.; Brey, G.P.; Okrusch, M. Steady state geotherm, thermal disturbances and tectonic development of the lithosphere underneath the Gibeon Kimberlite Province (Namibia). Contributions to Mineralogy Petrology 1996, 126, 181-198

80. Franz, L.; Brey G.P.; Okrusch, M. Reequilibration of ultramafic xenoliths from Namibia by metasomatic processes at the mantle boundary. Journal of Geology 1996,104 (5). 99-615

81. Riches A.J.V.; Ickerta R.B.; Pearson, D.G.; Stern, R.A.; Jackson S.E.; Ishikaw, A.; Kjarsgaard, B.A.; Gurney, J.J. In situ oxygen-isotope, major-, and trace-element constraints on the metasomatic modification and crustal origin of a diamondiferous eclogite from Roberts Victor, Kaapvaalcraton. Geochim. Cosmochim. Acta 2016, 174, 345-359

82. Ashchepkov I.V. Deep-seated xenoliths of the Baikal rift. Nauka, Novosibirsk 1991, 210 p. 
83. Hutchison, R.; Williams, C. T.; Henderson, P.; Reed, S. J. B.New varieties of mantle xenolith from the Massif Central, France. Mineral. Magazin 1986, 50, 559-565.

84. Mayer,B.; Jung, S.; Romer, R.L.; Pfänder, J.A.; Klügel, A.; Pack, A.,Gröner, E. Amphibole in alkaline basalts from intraplate settings: implications for the petrogenesis of alkaline lavas from the metasomatised lithospheric mantle. Contribution to Mineralogy and Petrology 2014, 167, 988-989.

85. Coltorti, M.; Beccaluvam L.; Bonadiman., C.; Faccini, B.; Ntaflos, T.; Siena, F. Amphibole genesis via metasomatic reaction with clinopyroxene in mantle xenoliths from Victoria Land, Antarctica. Lithos 2004, 75,115-13.

86. Gentili, S.; Bonadiman, C.,; Biagioni C.; Comodi, P.; Coltorti, M. Oxo-amphiboles in mantle xenoliths: evidence for H2O-rich melt interacting with the lithospheric mantle of Harrow Peaks Northern Victoria Land, Antarctica). Mineralogy and Petrology 2015, 109, 741-759.

87. Li, J., Zhang, S. 2002. Redox state of amphibole-bearing mantle peridotite from Nushan, Anhui Province in eastern China and its implications. Sci China (Series D) 45, 348-357

88. Ionov, D.A.; Bénard, A.; Plechov, P.Yu.; Shcherbakov, V.D. Along-arc variations in lithospheric mantle compositions in Kamchatka, Russia: First trace element data on mantle xenoliths from the Klyuchevskoy Group volcanoes Journal of Volcanology and Geothermal Research 2013, 263, 122-131.

89. Ionov D.A.; Hofmann A.W. Nb-Ta-rich mantle amphiboles and micas: implications for subduction-related metasomatic trace element fractionations. Earth Planet Sci Lett. 1995, 131, 341-356.

90. Foley, S. High-pressure stability of the fluor- and hydroxy-endmembers of pargasite and K-richterite. Geochimica et Cosmochimica Acta 1991, 55(9), 2689-2694.

91. Dalpé, C.; Baker, D.R. Experimental investigation of large-ion-lithophile-element-, high-field-strength-element- and rare-earth-element-partitioning between calcic amphibole and basaltic melt: the effects of pressure and oxygen fugacity. Contrib Mineral Petrol. 2000, 140(2), 233-250.

92. Zhang, B..; Hu, H.; Li, P.; Tang,O.; Zhou, W. Trace element partitioning between amphibole and hydrous silicate glasses at 0.6-2.6 GPa. Acta Geochimica 2019, 38, 414-429.

93. La Tourrette, T.; Hervig, R.L.; Holloway, J.R. Trace element partitioning between amphibole, phlogopite, and basanite melt. Earth Planet. Sci. Lett. 1995, 135, 13-30.

94. Foley, F.; Tiepolo, M.; Vannucci R. Growth of early continental crust controlled by melting of amphibolite in subduction zones. Nature 2002, 417, 837-840.

95. Faccini B.; Rizzo, A.; Bonadiman, C.; Ntaflos, T.; Seghedi, I.; Grégoire, M.; Ferretti, G.; Coltorti, M. Subduction-related melt refertilisation and alkaline metasomatism in the Eastern Transylvanian Basin lithospheric mantle: Evidence from mineral chemistry and noble gases in fluid inclusions. Lithos 2020, 364-365, 105516

96. Fumagalli, P., Poli, S. 2005. Experimentally determined phase relations in hydrous peridotites to 6.5 GPa and their consequences on the dynamics of subduction zones. J. Petrology 2005, 46, 555-578.

97. Ashchepkov, I.V.; Vladykin, N.V.; Ntaflos, T.; Downes, H.; Mitchel, R.; Smelov, A.P.; Rotman,A.Ya.; Stegnitsky, Yu.; Smarov, G.P.; Makovchuk, I.V.; Nigmatulina, E.N.; Khmelnikova, O.S.. Regularities of the mantle lithosphere structure and formation beneath Siberian craton in comparison with other cratons. Gondwana Research 2013, 23, 4-24.

98. Rosenthal, A.; Yaxley, G.M.; Green D.H., Hermann, J.. Continuous eclogite melting and variable refertilisation in upwelling heterogeneous mantle. Scientific Reports 2014, 4, 1-6.

99. Rosenthal, A.; Hauri, E. H.; Hirschmann, M. M. Experimental determination of C, F and H partitioning between mantle minerals and carbonated basalt, $\mathrm{CO} 2 / \mathrm{Ba}$ and $\mathrm{CO} 2 / \mathrm{Nb}$ systematics of partial melting, and the $\mathrm{CO} 2$ contents of basaltic source regions. Earth Planet. Sci. Lett. 2016, 412, 77-87.

100. Ionov, D.A.; Doucet, L.S.; Ashchepkov I.V. Composition of the Lithospheric Mantle in the Siberian Craton: New Constraints from Fresh Peridotites in the Udachnaya-East Kimberlite. Journal of Petrology 2010, 51, 2177-2210.

101. Pernet-Fisher, J.F.; Howarth, J.H.; Pearson, D.G.; Woodland, S.; Barry, P.H.; Pokhilenko, N.P.; Pokhilenko, L.N.; Agashev, A.M.; Taylor L.A. Plume impingement on the Siberian SCLM: evidence from Re-Os isotope systematics. Lithos 2015, 218-219, 141-154.

102. Cull J.P., O'Reilly S. Y., Griffin W.L. Xenolith geotherms and crustal models in Eastern Australia. Tectonophysics 1991, 192, N3-4, 359-366.

103. Manning, C.E. The chemistry of subduction-zone fluids. Earth Planet. Sci. Lett. 2004, 223, 1-16.

104. Foley, S. F.; Barth, M. G.; Jenner, G.A. Rutile/melt partition coefficients for trace elements and an assessment of the influence of rutile on the trace element characteristics of subduction zone magmas. Geochimica et Cosmochimica Acta 2000, 64, 933-938. https://doi.org/10.1016/S0016-7037(99)00355-5

105. Bedard, J. H. A catalytic delamination-driven model for coupled genesis of Archaean crust and sub-continental lithospheric mantle. Geochimica et Cosmochimica Acta 2006, 70, 1188 -1214.

106. Gregoire, M.; Bell, D.R.; Le Roex, A.P. Garnet Lherzolites from the Kaapvaal Craton (South Africa): trace element evidence for a metasomatic history. J. Petrol. 2003, 44,. 629-657

107. Chen, Y.; Niu, Y.; Xue, Q.; Gao, Y.; Castillo, P. An iron isotope perspective on back-arc basin development: Messages from Mariana Trough basalts. Earth and Planetary Science Letters 2021, 572, 117133

108. Carter, E.J.; O'Driscoll, B.; Burgess, R.; Clay, P.L. Multi-stage fluid infiltration and metasomatism in supra-subduction zone mantle: evidence from halogens and noble gases in the Leka Ophiolite Complex, Norway. Geochimica et Cosmochimica Acta 2021, 307, 258-280 ttps://doi.org/10.1016/j.gca.2021.04.028 
109. Bénard, A.; Koga, K.T.; Shimizu, N.; Kendrick, M.A.; Ionov, D.A.; Nebel, O.; Arculus, R.J. Chlorine and fluorine partition coefficients and abundances in sub-arc mantle xenoliths (Kamchatka, Russia): Implications for melt generation and volatile recycling processes in subduction zones. Geochimica et Cosmochimica Acta 2017, 199, 324-350.

110. Wang, D., Romer, R., L., Guo, J.-H., Glodny, G. Li and B isotopic fingerprint of Archean subduction. Geochimica et Cosmochimica Acta 2020, 268, 446-466

111. Song, S., Niu, Y., Su, L., Wei, C., Zhang, L., 2014. Adakitic (tonalitic-trondhjemitic) magmas resulting from eclogite decompression and dehydration melting during exhumation in response to continental collision. Geochimica et Cosmochimica Acta, $130,42-62$

112. Smart, K. A., Tappe, S., Woodland, A.B., Harris, C., Corcoran, L., Simonetti, A. 2021. Metasomatized eclogite xenoliths from the central Kaapvaal craton as probes of a seismic mid-lithospheric discontinuity. Chemical Geology, 578, 120286

113. Boettcher, A.L., O'Neil, J.R. 1980. Stable isotope, chemical, and petrographic studies of high-pressure amphiboles and micas: evidence for metasomatism in the mantle source regions of alkali basalts and kimberlites. Am. J. Sci., 280, pp. 594-621

114. Dawson, J.B. Smith, J.V. 1982. Upper-mantle amphiboles: a review. Mineralogical Magazine, 45, 35-46

115. Ernst, W.G., Liu, J. 1998. Experimental phase-equilibrium study of Al- and Ti-contents of calcic amphibole in MORB - A semiquantitative thermobarometer. American Mineralogist, 83, 952-969.

116. Popp, R.K., Hibbert, H.A., Lamb, W.M. 2006. Oxy-amphibole equilibria in Ti-bearing calcic amphiboles: experimental investigation and petrologic implications for mantle-derived amphiboles. Am. Mineral 91:54-66

117. Konzett,J.,Krenn,K.,Rubatto,D.,Hauzenberger,C.,Stalder, R.2014. The formation of saline mantle fluids by open-system crystallization of hydrous silicate-rich vein assemblages - evidence from fluid inclusions and their host phases in MARID xenoliths from the central Kaapvaal Craton, South Africa. Geochim. Cosmochim. Acta, 147, 1-25.

118. Medard, E., Schmidt, M.W., Schiano, P., Ottolini, L. 2006. Melting of Amphibole-bearing Wehrlites: an Experimental Study on the Origin of Ultra-calcic Nepheline-normative Melt. Journal of Petrology 47(3), 481-504

119. Foley, S.1992. Vein-plus-wall-rock melting mechanisms in the lithosphere and the origin of potassic alkaline magmas. Lithos, 28, pp. 435-453.

120. Schmidt, M.W., 1992. Amphibole composition in tonalite as a function of pressure: an experimental calibration of the Al-in-hornblende barometer, Contrib. Mineral. Petrol., 110, 304-310.

121. Schmidt M.W., Dardon A., Chazot, G., Vannucci, R. 2004. The dependence of $\mathrm{Nb}$ and Ta rutile-melt partitioning on melt composition and $\mathrm{Nb} / \mathrm{Ta}$ fractionation during subduction processes. Earth and Planetary Science Letters 226, 415-432

122. Sun, C.; Dasgupta, R., 2019. Slab-mantle interaction, carbon transport, and kimberlite generation in the deep upper mantle. Earth and Planetary Science Letters, 2019, 506, 38-52.

123. Trønne R. G. 2002. Stability range and decomposition of potassic richterite and phlogopite end members at 5-15 GPa. Mineralogy and Petrology. 74, 129-148.

124. Ridolfi, F., Renzulli, A., Puerini, M., 2010. Stability and chemical equilibrium of amphibole in calc-alkaline magmas: an overview, new thermobarometric formulations and application to subduction-related volcanoes, Contrib. Mineral. Petrol., 160, 45-66.

125. Wallace M.E., Green D.H. 1991. The effect of bulk rock composition on the stability of amphibole in the upper mantle: implications for solidus positions and mantle metasomatism. Mineral. Petrol. 44.

126. Wyllie, P.J1978. Mantle fluid compositions buffered in peridotite-CO2-H2O by carbonates, amphiboles and phlogopite. J. Geol., 86687-71

127. Hunt L., Stachel, T., McCandless, T.E., Armstrong, J., MuelenbachsK. 2012.Diamonds and their mineral inclusions from the Renard kimberlites in Quebec. Lithos142-143, 267-284

128. Waters, F.G.,Erlank, A.J., Daniels, L. 1989. Contact relationships between MARID rock and metasomatised peridotite in a kimberlite xenolith. Geochemical Journal 23, 11-17.

129. Konzett J., Armstrong, R.A., Sweeney, R.J., Compston W. 1998.The timing of MARID metasomatism in the Kaapvaal mantle: An ion probe study of zircons from MARID xenoliths. Earth and Planetary Science Letters. 16 133-145. 